Article

\title{
Green Energy-Green for Whom? A Case Study of the Kabinakagami River Waterpower Project in Northern Canada
}

\author{
Stephen R. J. Tsuji ${ }^{1, *}$, Dan D. P. McCarthy ${ }^{2}$ and Stephen Quilley ${ }^{2}$ \\ 1 School of Environmental Studies, Queen's University, Kingston, ON K7L 3N6, Canada \\ 2 School of Environment, Resources and Sustainability, University of Waterloo, \\ Waterloo, ON N2L 3G1, Canada; dmccarth@uwaterloo.ca (D.D.P.M.); squilley@uwaterloo.ca (S.Q.) \\ * Correspondence: 20srjt@queensu.ca
}

check for updates

Citation: Tsuji, S.R.J.; McCarthy, D.D.P.; Quilley, S. Green

Energy-Green for Whom? A Case Study of the Kabinakagami River Waterpower Project in Northern Canada. Sustainability 2021, 13, 9445. https://doi.org/10.3390/su13169445

Academic Editor: Meg Parsons

Received: 9 July 2021

Accepted: 18 August 2021

Published: 23 August 2021

Publisher's Note: MDPI stays neutral with regard to jurisdictional claims in published maps and institutional affiliations.

Copyright: (c) 2021 by the authors. Licensee MDPI, Basel, Switzerland. This article is an open access article distributed under the terms and conditions of the Creative Commons Attribution (CC BY) license (https:/ / creativecommons.org/licenses/by/ $4.0 /)$.

\begin{abstract}
Green energy has become a term that heralds efforts of environmental conservation and protection worldwide; however, much of it is marred with questions of what it means to be green. More precisely, it has become a question of Green for whom? While many of the impacts of supposed green energy projects are local in their reach, some may be more regional in their scope, such as hydroelectric power. Hydroelectric power generation negatively impacts the environment and people who rely on the environment for sustenance, such as, Indigenous peoples of northern Canada. Taking into account their position with respect to the areas impacted by these green projects, many Indigenous peoples have voiced their concerns and doubts concerning green energy, which is purported to be a mode of energy production that champions the environment. The Kabinakagami River Waterpower Project serves as a case study for both the potential effects of the project and the different views associated with these endeavors. If nothing else, the accounts and testimonies found within shall stand as a testament to the hubris of calling an energy project green without properly assessing and considering the impacts. While these statements relate to the case presented, they also carry significance in the wider world due to the numerous Indigenous communities around the world that are having their spaces slowly being encroached upon in the name of sustainable growth, or green energy. This will especially be true in the post-COVID-19 period where green energy and a green economy are being touted as a way towards state and worldwide recovery.
\end{abstract}

Keywords: First Nations; green energy; hydroelectric power; impacts; Indigenous perspective; two-eyed seeing; Canada; worldwide

\section{Introduction}

Following the worldwide financial crisis of 2008, green energy has garnered more interest from a policy-based perspective, leading many countries to introduce green economy stimulus packages [1,2]. Globally, the definitions for green energy vary [3]; however, most possess core concepts that are clearly expressed in the definition provided by Bhowmik: "clean sources of energy that have a lower environmental impact compared to conventional energy technology [e.g., gas, coal]" [4] (p. 796). Given the definition provided, hydroelectric power would be considered green energy by many people, because it is generally considered to be both clean and renewable [5]. Although hydroelectric power is typically thought to be emissions-free with respect to greenhouse gases, it is not [6]. Kahn et al. [7] (p. 6063) report that hydroelectric "projects will generate significant greenhouse gas emissions from deforestation and decay of organic matter in the reservoirs." Additionally, while hydroelectric power generation is considered renewable, it is not considered environmentally inconsequential [8], even with claims of environmental superiority in comparison to other power options [9]. Hydroelectric power has been hailed to be the most important renewable energy source in the world, and important in helping to address climate change [10].

Over the last several decades, hydropower's use within the world as an effective energy source has been increasing steadily [11]. China, India, Canada, Brazil and the 
United States are all examples of where the popularity of hydropower is surging due to the recognition of opportunity within the industry $[12,13]$. These opportunities are further accentuated by the push for greener modes of production [12] and the overarching discourse that seeks to combat climate change. Even amidst the pandemic and the stalling of hydropower projects, power generation has increased throughout the last year [14]. At an international level, it is difficult to refute the importance of hydropower in the current energy market.

However, at a local-scale, there are notable impacts on the environment $[13,15]$ and Indigenous people [16]. These impacts upon Indigenous populations, while localized, are not exclusive to a single nation; these harms can be seen worldwide through the numerous hydropower projects. In the instance of Malaysia's Bakun dam, the displaced peoples faced many new trials due to the inadequacy of the compensation and refusal to acknowledge the scope of the effects [17]. Many of the financial difficulties were compounded by environmental assimilation practices that made it impossible for them to resume their previous lifestyle [18]; instead, they were forced to adapt to the more urbanized setting [17]. Similar instances can be seen in other areas of the world such as Costa Rica, the Amazon, the Congo, the Balkans and the Himalayas $[11,19,20]$. In all cases, we-who interact with this discourse-must be aware of how different rhetoric is used to further obfuscate these impacts that would receive backlash otherwise. In the past two decades, studies have shown that we must be especially careful of green energy and how the term green is defined [3,12], and on what scale it is being considered.

In Canada, where a federated system of government exists, the Government of Ontario passed Bill 150 [21] with the intention of making Ontario:

"North America's green energy leader ... first, making it easier to bring renewable energy projects to life [by streamlining the approval and permitting processes], and secondly, creating a culture of conservation [through regulations and incentives] ... These two thrusts combined would support a new green economy for this province and help create sustainable green employment for Ontarians ... [and] would offer an attractive price for renewable power, including wind ... solar, hydro [added emphasis] ... Ontario would join the ranks of global green power leaders like Denmark, Germany and Spain." [22] (pp. 4951-4952)

Green energy was never defined in the Green Energy Act (2009) [3], while renewable energy was defined, and included hydroelectric power [23]. During deliberations for the Green Energy Act, renewable energy was often equated with green energy in the Legislative Assembly of Ontario by those that proposed it [24]. In public hearings, held by the Standing Committee for General Government, it was asserted that green energy should not compromise the environment or pose threats to health and safety; instead, it should improve the environment by decreasing greenhouse gas emissions [25-27].

In the discussions of the Legislative Assembly of Ontario on the topic of green energy, the protection of the environment and human health was emphasized:

“Our government's [i.e., the Liberal Party's majority government] goal of building more green energy projects faster and in a timely way will always be balanced with an equally important objective of preserving and protecting our air, land and water, our ecosystems [which by definition in Ontario includes humans] and wildlife." [28] (p. 5013)

"[C]ertainty for the people of Ontario that their interests, their health and their safety will come first." [29] (pp. 411-412)

Thus, with green energy there are certain assumptions of characteristics that are associated with the term from public and political perspectives. One of the widely supported stances is: for green energy to be considered green, it should not negatively impact the environment. 
The present paper will examine the assertion that hydroelectric development is green in northern Ontario, Canada, from a First Nations' perspective making reference to Indigenous knowledge. In the past, Indigenous knowledge was transmitted orally within and between generations, being both cumulative and dynamic [30]. Indigenous knowledge was often considered anecdotal by colonizers [31], but the Berger Inquiry in Canada [32], the World Commission on Environment and Development (1987) [33], the United Nation's "Earth Summit" [34], and the Convention on Biological Diversity [35] started to change nonIndigenous peoples' perceptions and increased the credibility of Indigenous knowledge systems worldwide. Recently, it was reported that Indigenous people have managed or have tenure rights to approximately 38 million $\mathrm{km}^{2}$ of land in 87 countries (or distinct political regions) [36]. Moreover, their stewardship over the land for millennia has left the land relatively pristine, suggesting that Indigenous governance norms can maintain sustainable-human landscape relationships in many regions worldwide [36-38]. Studies have suggested that Indigenous Peoples' lands and their management practices can help inform biodiversity conservation efforts and sustainable development agendas (e.g., climate change) worldwide [37,38].

For complex resource development and environmental issues, such as hydroelectric development on Indigenous homelands, the use of different perspectives gives a more complete understanding of a complex issue [39-41]. This two-perspective, or "two-eyed seeing", approach prioritizes the need to "Learn ... to see from one eye with the best in ... Indigenous ways of knowing, and from the other eye with the best in Western (or mainstream) ways of knowing ... and learn to use both these eyes" [42] (slide 15). Moreover, in Canada there is the legal fiduciary responsibility to consult with Indigenous peoples when a proposed project may infringe on Aboriginal—this dated term was defined in the Canadian Constitution Act (1982) [43] to include First Nations, Inuit, and Metis peoples-and/or treaty rights [44]. With this said, the following analysis will make use of science and Indigenous knowledge as complementary sources of knowledge.

A non-Indigenous scientific perspective will be presented in a brief literature review. While the Kabinakagami River Hydroelectric Project in northern Ontario will be used as the case study, due to the fact that the environmental assessment (EA) process was initiated just after the passing of the Green Energy Act (2009), and this hydroelectric project had a unique First Nations factor. It will be established what was known about the impacts of hydroelectric development projects at the approximate time of the passing of the Ontario Green Energy Act (2009) and what is presently known, and whether the evidence supported the green assertion. Next, the context of the case study will be presented, followed by a description of the Kabinakagami River Hydroelectric Project, and then the method of approach. Results of the study will be presented, from an Indigenous perspective, and discussed with respect to the development of hydroelectric generating stations on Indigenous homelands. The insights that are gained from these questions and discussions will be summarized to answer the larger question concerning green energy-green for whom?

\section{Background}

\subsection{The Scientific Perspective}

Historically, there has been a disconnection between what the public believes are the environmental and social-cultural consequences of hydroelectric development projects and what is actually occurring [45]. Hydroelectric development is not as benign as first thought, with impacts including the following: emission of greenhouse gases; methylmercury bioaccumulation; and habitat change including fragmentation [46]. While the public may believe that hydropower projects avoid greenhouse gas emission [47], this unfortunately is a misconception [6]. As stated by Tremblay et al. [48] (p. s509), after the flooding of terrestrial ecosystems in the creation of a reservoir, "over the first few years, bacteria decompose a fraction of the organic carbon that was stored in the vegetation and in the soils, partly converting it to carbon dioxide $\left(\mathrm{CO}_{2}\right)$ and methane $\left(\mathrm{CH}_{4}\right)$." After a 10-year period post-flooding, greenhouse gas emissions for reservoirs become comparable to those of 
natural lakes as reported for Canada [48-50]. Nevertheless, small physical features created during reservoir construction (e.g., a small bay) can result in significant $\mathrm{CO}_{2}$ emissions of up to $6000 \mathrm{mg} \mathrm{CO}$ / day even after 20 years post-flooding, as reported for a northern Quebec (Canada) hydroelectric reservoir [48]. In addition, the geographical location of a reservoir and their catchment area can influence greenhouse gas emissions [51]. For example, it has long been known that some Amazonian reservoirs can greatly exceed emissions from fossil-fueled power plants [46]. Clearly, hydropower is not emission-free [52].

After impoundment for hydroelectric generation purposes, the flooded area undergoes a change. Organic matter containing inorganic mercury undergoes bacterial decomposition in the flooded area, whereby the inorganic mercury is transformed by the bacteria into methyl mercury, with most of the methyl mercury remaining in the flooded soil [53]. However, a portion of the methyl mercury enters the food chain "through aquatic organisms at the bottom of the food chain such as zooplankton, insect larvae, or benthic organisms and is biomagnified through the food chain, reaching maximum concentrations in piscivorous fish" [53] (pp. 493-494). Typically, it has been reported worldwide that the methyl mercury in the water and fish decreases over time post-impoundment [54], as long as there is no additional flooding [53]. Methyl mercury concentrations in non-piscivorous fish, such as, whitefish (Coregonus clupeaformis) decreased faster than in piscivorous fish, such as, walleye (Sander vitreus) and northern pike (Esox lucius); by 30 years post-impoundment the methyl mercury concentration in most (not all) fish species were at background levels [54] (p. 104). In the eastern James Bay region of northern Quebec, Canada, "concentrations of all [fish] species increased rapidly after impoundment, peaking after 4 to $11 \mathrm{yr}$ in nonpiscivorous species and after 9 to $14 \mathrm{yr}$ in piscivorous species, at levels $2-8$ times higher than those measured in surrounding natural lakes ... [a return to background levels, typically occurred] after 10 to $20 \mathrm{yr}$ for all non-piscivorous species and after 20 to $31 \mathrm{yr}$ in most piscivorous species, if no additional flooding occurred" [53] (p. 493).

Hydroelectric dams and reservoirs provide hydraulic head; thus, the release of water through turbines on a timetable can match periods of energy demands (i.e., yearly, seasonal, and with run-of-river impoundments, daily; [55]). However, through impoundment, the river system is fragmented, and altered river flows reduce flow velocity and the number of rapids, altering wetland and floodplain ecosystems [55]. Dams also disrupt the dispersal and movement of riverine organisms; alter the in-channel physical environment; and impact riverine biodiversity and species abundance. Worldwide, freshwater ecosystems are now among the most threatened ecosystems $[55,56]$. For river systems with hydropower facilities, the passage of fish downriver through the facility may result in exposure to a number of stressors such as: rapid decompression, blade strike and collision, which unduly impacts fish morbidity and mortality [57]. The passage of migrating fish upriver can be accommodated through the incorporation of fish bypasses [55]; these fish passes come in many different forms [58].

Social impacts can occur upstream of the hydroelectric site, at the dam, and/or downstream of the dam. Impacts include but are not limited to displacement of Indigenous people off of their traditional lands, and the alteration of their culture and way of life; and the loss of sources of income, such as trapping and subsistence activities through barriers being erected to a variety of ecological services [7]. However, more recent run-of-the-river installations are reported to cause less environmental damage compared to the large impoundments that have historically been used with hydroelectric power generation [59]. The relatively benign impacts of run-of-river generation facilities have been espoused for decades [56], pointing to the design of the dam: "In the run-of-the-river hydroelectric projects, the purpose of the dam is essentially to direct and control the flow of the stream and little water is impounded" [60] (p. 256). However, there is limited peer-reviewed studies [52] to support the assumption that run-of-the-river facilities are environmentally less damaging; and results from studies of downstream ecological effects of small humanmade impoundments have been mixed [61]. In a review by Anderson et al. [56], they report that the use of in-channel barriers with water flow alteration can have a myriad of 
potential physical and ecological effects. For example, the fragmentation of the river may impact the downstream movement of sediment, organic matter, nutrients, plant propagules, aquatic organisms including fish; and upstream movement of migratory fish would be impeded [56]. The physical habitat would also be altered; a lentic environment would be created with raised water levels upstream of the dam, with reduced flow variability, velocity and turbulence [56]. Meanwhile, downstream from the dam, it has been suggested that the higher velocity and more turbulent flow exiting the run-of-the-river facility would erode bed sediment, undercut banks, and impact bar formation [56]. In a study by Bilotta et al. [52] examining the effects of run-of-the-river facilities on fish communities in temperate streams and rivers, analyses revealed a significant effect of run-of-the-river facilities during construction and operation on a number of fish species. Run-of-the-river facilities have relatively lower, but not zero, greenhouse gas emissions compared to other sources of power generation [6,52].

\subsection{History of Hydroelectric Power in Ontario}

Historically, hydroelectric power generation has been one of the main drivers of economic prosperity in several Canadian provinces, such as Quebec and Ontario. In Canada, the provinces hold jurisdiction over natural resources [43], including waterpower generation. In 1906, the Hydro-Electric Power Commission of Ontario, known as Ontario Hydro after 1974 [62], was formed as a crown corporation, that is, a publicly owned utility company of the Government of Ontario [63-65]. The year of 1906 was also of importance in Ontario because the western James Bay region of northern Ontario, Canada, was "ceded" by First Nations people to the Government of Canada from a common law perspective [66], with Ontario being a signatory, through the signing of Treaty No. 9 [67] in 1905-1906. The western-southern Hudson Bay region of northern Ontario was "ceded" through the Treaty No. 9 Adhesions [68]. Treaty No. 9 and its adhesions were needed because the British Crown - Canada was one of Britain's colonies-recognized Indigenous rights to land in North America [66,69]. Thus, Indigenous homelands needed to be "ceded" or surrendered to Canada to allow for development on Indigenous homelands [66,69]. However, Indigenous people maintain that they did not own the land so could not have ceded the land through the signing of treaties; from an Indigenous worldview, the treaties were agreements to share the land with the colonizers [66,69].

As stipulated in Treaty No. 9, potential hydroelectric sites capable of generating 500 horsepower were not to be included in any of the reserves set aside for Indians; note that historically, in government documents, the term "Indians" was incorrectly used in reference to First Nations peoples of Canada [69]. Prior to Treaty 9, the importance of the northern Ontario region for hydroelectric power generation, to enable settlement and resource development, was recognized $[63,64]$. The majority of potential waterpower sites in Ontario are located on the major river systems of northern Ontario: the Moose, Albany, Attawapiskat, Winisk and Severn Rivers [70]. Of these five major river systems in the region, only the Attawapiskat, Winisk, and Severn River Basins are pristine; hydroelectric development has occurred in the southern portions of the Moose and Albany River Basins (Figure 1).

When hydroelectric development began in the southern areas of the Moose and Albany River Basins in the early part of the 20th century, there was no consultation with the First Nations communities or any forewarning $[63,64,71]$. The consequences of hydroelectric development were severe and wide-ranging. Impacts included, but were not limited to, major flooding of cultural sites and relocation of First Nations communities due to the erection of dams $[63,64,71]$. Flooding also impacted riverine, boreal, and wetland ecosystems; this also meant that subsistence activities were affected, especially fishing due to mercury contamination $[63,64,71]$. After several First Nations' grievances over past hydroelectric developments were prioritized by the Government of Ontario [72] and several addressed, Ontario Power Generation entered into partnerships with Moose Cree First Nation in 1994, and the Lac Seul First Nation in 2006 [73]. They began their move to 
refurbish old hydroelectric power generating facilities on the Mattagami River that came online in 2014-2015, and developed a new hydropower plant on the English River that came into service in 2009 [73,74].

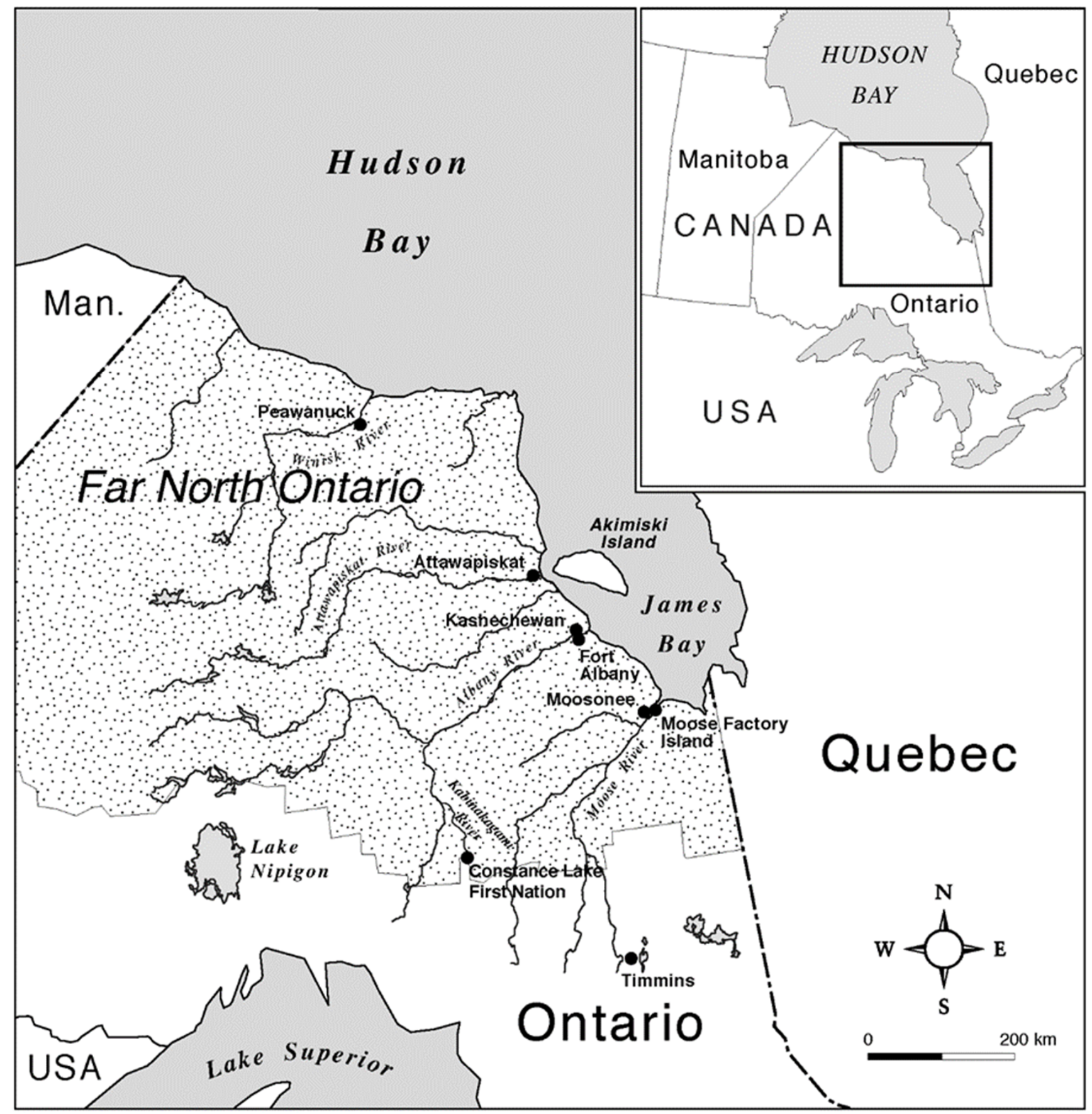

Figure 1. The rivers of Ontario's Far North region.

\subsection{Hydroelectric Development in the Albany River Basin: Chard River and Hat Island}

In 2008, a Treaty Forum on "Rights to Water Resources" was held in Timmins, northern Ontario, for the First Nations of the western James Bay region [75]. During this forum, Government of Ontario representatives discussed potential hydroelectric development projects located on the major river systems of northern Ontario: the Moose, Albany, Attawapiskat, Winisk and Severn Rivers. During the discussions, the Hat Island and the Chard River sites near the Albany River forks were identified by the government without First Nations input, 
as the sites with the greatest potential for hydroelectric development in the Albany River basin [76]. In 2009, the Mushkegowuk Environmental Research Centre in collaboration with the Northeast Science and Information Section of the Ministry of Natural Resources, Government of Ontario, conducted a baseline habitat and fish assessment study at the Hat Island and Chard River sites [76,77].

The two communities downriver of these two potential hydroelectric generating sites, Fort Albany First Nation and Kashechewan First Nation, gave full support to this habitat and fish assessment study [76]. In 2009, Fort Albany First Nation in conjunction with the University of Waterloo, Waterloo, Ontario, began collecting high-resolution satellite imagery of the Hat Island and Chard River area to be used for visual and geospatial analyses [78]. There were considerable levels of investment being put into these baseline studies by Fort Albany and Kashechewan First Nations for the Hat Island and Chard River sites; thus, the 17 June 2010 notification of the Kabinakagami River Waterpower Project came as a complete surprise to Fort Albany and Kashechewan First Nations [70].

\subsection{Kabinakagami River Waterpower Project}

The proposed Kabinakagami River Waterpower Project was a joint-venture partnership of Constance Lake First Nation and Northland Power Inc. [59]. The project was "being encouraged by the government of Ontario under the Green Energy and Green Economy Act [23] and the Feed-In Tariff program" [79] (p. 12) to "generate environmentally sustainable hydroelectric green power [added emphasis]" [80] (pp. 1-2). This green energy project consisted of four run-of-river hydroelectric generating stations with a combined capacity of 26 megawatts and was to be located on crown land, on the Kabinakagami River-a tributary of the Albany River [80].

Each hydroelectric station was designed with an earth-fill dam to be placed across the Kabinakagami River, to form a head pond, which would result in a new area of inundation [80]. An intake channel would divert river flow into the powerhouse intake, while a tailrace channel would direct water flow from the powerhouse back to the river downstream [59]. Each tailrace would require excavations "to convey the water from the powerhouse across an existing bench back to the main river course" [80] (pp. 2-16). Due to the run-of-river design, the zone of influence for each proposed hydroelectric station was asserted to be "from the upstream end of the proposed head pond to the downstream end of the tailrace" [80] (pp. 1-5). The area of influence was also reported to include the new access roads and a new transmission-line corridor required to connect the hydroelectric generating stations to the existing provincial-power grid [80].

\subsection{Environmental Assessment Process}

Since, the environment was never mentioned in the Canadian Constitution Act [43]; consequently, the environment is a shared responsibility between two levels of government (i.e., the Government of Canada and the provinces). The result is environmental assessments (EA) that exist at both the federal and provincial levels; the EAs can be harmonized or dealt with on an ad hoc basis. In Ontario, two types of EAs existed: the more rigorous Individual EA and the streamlined Class EA [81]. At the time of the Kabinakagami River Waterpower Project, there were 11 Class EAs in Ontario for projects that were routinely done and managed [81]. For hydroelectric projects, the Ontario Waterpower Association's Class EA outlined the requirements, relevant approvals and permissions required [70,79].

In Canada, the federal government, historically, regulated hydroelectric projects through the Canadian Environmental Assessment Act (1992) [82,83]); however, this changed when the Canadian Environmental Assessment Act (2012) [84] was enacted through two omnibus bills, C-38 and C-45 [85]. The streamlining of the federal environmental assessment process resulted in two important changes with respect to Canadian Indigenous peoples and hydroelectric projects: Indigenous people would have little opportunity to participate in EAs due to the streamlining of the process and funding cuts; and the number of proposed projects that would require the federal EA process would be limited $[70,85,86]$. 
These changes to the Canadian Environmental Assessment Act (2012) [84] impacted the federal EA process for the Kabinakagami River Waterpower Project; the federal Environmental Screening EA required under the previous Canadian Environmental Assessment Act was no longer required due to the streamlining measures introduced [59].

\subsection{Valued Ecosystem Component (VEC)}

A valued ecosystem component (VEC) can be defined as follows:

"Any part of the environment that is considered important by the proponent, public, scientists and government involved in the assessment process. Importance may be determined on the basis of cultural values or scientific concern." [87]

At the time, there was a difference between how VECs were viewed at the Government of Ontario level and the federal government level because of the difference between the two levels of government with how the environment was defined. The Ontario Environmental Assessment Act (1990) [88] explicitly mentioned humans in its definition:

"environment' means,

(a) air, land or water,

(b) plant and animal life, including human life [added emphasis],

(c) the social, economic and cultural conditions that influence the life of humans [emphasis added] or a community,

(d) any building, structure, machine or other device or thing made by humans,

(e) any solid, liquid, gas, odour, heat, sound, vibration or radiation resulting directly or indirectly from human activities, or

(f) any part or combination of the foregoing and the interrelationships between any two or more of them," (Part 1, Interpretation 1(1)).

Meanwhile, the Canadian Environmental Assessment Act (2012) [84] interpreted the environment biophysically to mean:

"the components of the Earth, and includes

(a) land, water and air, including all layers of the atmosphere;

(b) all organic and inorganic matter and living organisms; and

(c) the interacting natural systems that include components referred to in paragraphs (a) and (b)." (Interpretation, Section 2(1)).

In the final Environmental Report [59] submitted to the Government of Ontario for the Kabinakagami River Waterpower Project to meet the obligations of the Ontario Waterpower Association's Class EA, seven Environmental Components were identified with associated VECs: Surface Geology and Soils; Surface Water Quality and Quantity; Hydrogeology, Groundwater Quality and Quantity; Air Quality and Climate; Fish and Fish Habitat; Vegetation, Wetlands and Wildlife; and Social/Socioeconomic Environment [59] (Table 1.2 Valued Ecosystem Components, pp. 1-15). However, no information was provided in the Environmental Report [59] about who identified the VECs, the rationale for the choice of VECs, and if there was Indigenous input other than the Indigenous proponent of the project [89].

Just before the Kabinakagami River Waterpower Project EA was conducted, the Comprehensive Study Report EA for the Lower Mattagami River Hydroelectric Complex Project in the Moose River Basin of northern Ontario was completed [90]. In this Comprehensive Study Report EA, the Moose Cree First Nation provided a description of the existing environment from their worldview because the description of the environment was an integral part of the EA process [90], and was essential for the identification of potential impacts from different perspectives. The Moose Cree description of the environment (see Table 1 for more details):

"Comes from our [Cree] worldview as a people which make up one of many parts of our environment. This is intended to provide counterpoise to the western concept of the environment that is statistical and quantitative in nature and does not by itself adequately 
capture the spiritual, cultural and physiological connection of the Moose Cree people to nature and our deep rooted sense of reciprocity with the land, water and animals ... our unique way of perceiving, knowing and describing our environment. Our social (ritual, ceremony, feast) and cultural (hunting, fishing, trapping) practices regarding the natural resources of our homelands have been built on spiritual relationships and understandings of the land, water and wildlife. Thus, a sacred acknowledgement and bond to the natural world, our place and responsibilities within it sustains us and continues to ensure our existence ... Likewise, the Moose Cree respect that 'others' as well have different paths to awareness and knowledge of their worlds; none greater or better than the other." [90] (pp. 1-9)

The Moose Cree perspective at the very least should have informed the Kabinakagami River Waterpower Project EA-First Nations consultation process with respect to VECs, as the Moose Cree perspective was the only First Nations perspective comprehensively documented for the region-it did not.

Table 1. A brief description of the Moose Cree perspective of the environment [90] (pp. 3-9).

Illiuu: People

Moose Cree Laws: Principles of Reciprocity

Niipin, Da Kaw Kuk, Pi Poon, Siigwiin: Seasons

Askii: Land

Niipii: Water

Ookamauu: "Boss"
"'Mushkegowuk', meaning 'people of the muskeg or land'" "The animals were the true First Peoples"

"You see the fundamental laws or principles that we have followed came from the land and animals. The trees, animals, fish and birds gave themselves to us, but they expected us to acknowledge, respect and honour those who had given life so that we may live."

"Our ancestors viewed the animals, fish, birds, rivers, lakes and land as inter-connected, so today we know that we are only one small part in the greater world of land and animals ... depend on the seasonal changes"

"We love our land and have a special, sacred attachment to it. Our philosophy is we believe that we must care for the land as it has cared for us ... The land is the sacred resting places of our ancestors and together, forms our collective cultural memory and oral history"

"Water is the source of our life and is one of the most valued elements in our environment. Clean water contributes to spiritual, mental and physical wellbeing. We've always been able to trust its refreshment, nourishment and nutrients ... In our belief system, fish were so important that our Elders spoke of and believed in a fish "master" that cared for all fish."

\section{Towards a New Economic Relationship}

"Corporations such as the Ontario Power Generation (OPG) are seeking a new relationship with our peoples. In the spirit of our forefathers, both our groups will practice respectful business dealings and conscientious environmental stewardship based upon the philosophies, knowledge and technology of both our societies."

In order to address the question of green for whom with respect to the Kabinakagami River Waterpower Project in northern Ontario, Canada, it is imperative to incorporate along with the non-Indigenous scientific perspective already presented, an Indigenous perspective from northern Ontario First Nations. The use of these perspectives in a complementary manner respectful to both [39] will allow for a more complete understanding of the impacts of hydroelectric developments on the First Nations peoples, communities, and cultures. The perspectives of Constance Lake First Nation, the co-proponent of the Kabinakagami River Waterpower Project, is especially important due to their role in this project; the downstream First Nations on the Albany River, namely, Fort Albany and Kashechewan are also of importance due to the potential impacts of the project. 


\section{Methods}

\subsection{Thematic Analyses}

A thematic approach is more culturally appropriate for use with Indigenous peoples compared to other qualitative methods, such as a content analysis. A thematic analysis allows for the examination of extended passages to ascertain meaning, which is important with respect to oral traditions typically used by Indigenous peoples. Oftentimes meaning is ambiguous; narration often has to be thought about and revisited several times before the true meaning becomes apparent to the "listener," if it ever does. Thus, a content analysis approach counting the absolute number of times and/or frequency of words and/or phrases that appear in the data [91] is not particularly relevant nor culturally appropriate with respect to many Indigenous peoples of the world.

The collection and analyses of primary and secondary data allowed the answering of the research question (Green energy — green for whom?). Firstly, it was important to establish an Indigenous perspective (worldview) of the environment and to make note of Indigenousidentified VECs in order to understand the impacts of hydroelectric development (existing and predicted) in northern Ontario, and especially on the Albany River watershed of the proposed Kabinakagami River Waterpower Project. Secondly, it needed to establish how past experiences with resource development and hydroelectric development, in particular, have shaped the First Nations perspectives. With this information in hand, the green for whom question was explored in the context of the Kabinakagami River Waterpower Project.

Both primary and secondary qualitative data was analyzed using a combination approach of deductive and inductive thematic coding [92,93]. The data was first deductively analyzed by hand into themes on paper [94], using a template organizing approach [92] whereby the Moose Cree environmental perspective and values-being the most comprehensive First Nations' perspective on the importance of the environment, and specific to a hydroelectric generation project in northern Ontario-informed our thematic framework. The Moose Cree informed environment-thematic framework included four main themes to be used as a coding template: First Nations' Codes of Conduct (or values), land, water, and development. Subthemes to these main themes arose through inductive and iterative thematic coding and revealed additional insights by letting "themes" emerge from the data itself $[91,93]$. In this way, the research question-Green for whom? - could be answered from an Indigenous perspective and a non-Indigenous scientific perspective (Section 2.1) in the context of the Kabinakagami River Waterpower Project case study.

\subsection{Data Sources}

Data were collected from primary sources to present a northern Ontario, First Nations perspective on the environment including the value of the environment in addition to the Moose Cree First Nation viewpoint. Hansard verbatim transcripts of the Standing Committee on General Government public hearings for Bill 173 (the Mining Amendment Act, 2009) [95] and Bill 191 (the Far North Act, 2010) [96] were being considered during the same time period that the Kabinakagami River Waterpower Project EA was being conducted [31]; consequently, they are of contextual value with respect to the research question. These Hansard transcripts were read in their entirety. Bills 173 and 191, and Bill 150 (the Green Energy Act, 2009) [21] were important because of the potential impacts resource development would have in northern Ontario. The Hansard transcripts for the Green Energy Act (2009) public hearings were read in their entirety but were not included in the present study because Indigenous content was limited and not from elected-First Nations representatives [44]. Chiefs \& Councils are a construct of the Indian Act (2011) [97], and are elected by communities at the First Nations' level of government. Chiefs \& Councils are the local governing body. Tribal Councils (and other supra-level First Nations organizations) consist of First Nations Chiefs in a regional or provincial or territorial area, and are a political body. Grand Chiefs \& Deputy Grand Chiefs are typically not elected by the people, but some are elected regionally by the people (e.g., Grand Chief \& Deputy Grand Chief of the Mushkegowuk Tribal Council). 
The comments from the Constance Lake First Nation open houses for the Kabinakagami River Waterpower Project [59] were read in their entirety, and provided insight into the deeply divided community with respect to the hydroelectric project. The Kabinakagami River Waterpower Project Report EA produced by Hatch [59] provided some insight into how environmental values were defined by the members of Constance Lake First Nation. Correspondence requests for a bump-up (or Ministerial Part II Order [98]) of the Kabinakagami River Hydroelectric Project from a Class EA to a more comprehensive Individual EA, by Chief Andrew Solomon of Fort Albany First Nation [99], and his successor Chief Rex Knapaysweet [100] were used to give insight into the perspective of this downriver community with respect to the environment and potential impacts of the project.

Other sources of primary and secondary data included interviews from previous studies with Albany River First Nations downstream of Constance Lake First Nation. In a land use planning initiative requested by Fort Albany First Nation, semi-directed interviews were conducted with Fort Albany First Nation Chief \& Councillors and Elders, and at EA training sessions [101,102]. During the training sessions, participants were "asked to identify what they valued most with respect to environmental, social, cultural and economic issues or VECs" to supplement the interview data [102] (p. 4). A number of VECs or "substantive values" were identified during the semi-directed interviews and the training sessions; these should be viewed as not being mutually exclusive [102] (pp. 5-13).

\section{Results and Discussion}

\subsection{First Nations' Codes of Conduct (or Values)}

\subsubsection{Inherent Rights}

The First Nations' people of northern Ontario revere the environment and believe it is their inherent right and duty to protect the environment for future generations as seen in the following passages from First Nations' leadership:

"The north is our homeland and we govern and protect it through our inherent right, given to us by the Creator. Since time immemorial, our people have exercised our inherent right and protected the lands. That is why they are still in pristine condition. And we will continue to protect our lands for future generations ... the Far North ... We have lived there for close to 10,000 years and ... will continue to protect the natural environment"

(Grand Chief of Nishnawbe Aski Nation, Stan Beardy) [103] (pp. 828-831)

Our concepts of preserving Mother Nature ... we have thousands of years of intergenerational experience with how to live in harmony with the land and preserve it, not destroy it in a few years [through resource development] (Councillor for Kitchenuhmaykoosib Inninuwug (also known as Big Trout Lake First Nation), Sam McKay) [104] (p. 912).

In Canada, from a common law perspective, these "Aboriginal" (or inherent) rights as well as treaty rights have recently been constitutionally protected [43], but these rights as mentioned above have existed for millennia, well before the existence of common law. Of great importance, as noted above by the Grand Chief of Nishnawbe Aski Nation, Stan Beardy) [103], only the Creator can give or take away this right. In Canada, there is great effort going into the revitalizing of Indigenous laws with resulting protections of the environment [105]. Globally, Indigenous people assert that they do need state-sanctioned recognition of these Indigenous rights for these rights to exist [36]. Indigenous people around the world have exerted their inherent rights with respect to their governance over their homelands for millennia to great positive effect, with respect to sustainability [36].

\subsubsection{Stewardship and Reciprocity}

Chief Keeter Corston of Chapleau Cree First Nation [106] (pp. 955-956), northern Ontario, provided a succinct description of First Nations' relationship with the land. "When we're talking about the land, the people are connected to the land. First Nations people are stewards of the land; it's part of us." Environmental stewardship can be simply put as, look after "what the Creator gave us for our sustenance and cultural pursuits" [102] (p. 12). 
This northern Ontarian First Nations' perspective, and in general Canadian Indigenous perspective that the land is to be respected and protected, sharply contrasts the colonial viewpoint that the land is a resource to be exploited for capitalistic gains [107-109]. Other Indigenous peoples worldwide, such as in Australia, believe that "country" is a living, multidimensional entity [110] and must be cared for through "caring for country" stewardship activities that result in environmental, spiritual, and human health and wellbeing benefits [111],

In the Far North of Ontario (Figure 1), while non-Indigenous people assume that the land is untouched by human activity, and a new frontier waiting to be developed, this is far from the truth, as elucidated by the First Nations' people that live there:

"We have protected and governed the lands for thousands of years. The legacy of our care is that our use has been next to invisible. To you, the lands look untouched. They aren't. They've just been touched by the Anishnawbe in accordance with Anishnawbe laws and customs. That's why the lands are in the condition they are in. We will continue to protect and govern the lands for future generations."

(Special Envoy of Nishnawbe Aski Nation, Frank Beardy) [112] (p. 953)

"A lot of people say it's our last frontier. What the government instead should be doing is congratulating all of the First Nations and NAN territories for keeping the land in its natural state: the way it is. We have not contaminated and harmed our land."

(Chief of Weenusk First Nation, George Hunter) [113] (p. 956)

Other First Nations groups across Canada have also expressed frustration with this non-Indigenous misconception that Indigenous homelands are empty; thus, waiting to be "developed and stripped of its resources without harming anyone or anything" as justification for unsustainable development, as noted by the Cree Nishiiyuu Council of Elders of northern Quebec [114] (p. 1). Moreover, despite the global heterogeneity of Indigenous peoples, a commonality between the groups is their contention that Indigenous stewardship represents one of the oldest forms of sustainable use of the environment [36]. This is why there has been a recent upswing of research interest in Indigenous management of their homelands; perhaps it is a way toward a more sustainable world with respect to conserving biodiversity and addressing climate change on a global scale $[37,38]$.

\subsection{Land}

\subsubsection{Reciprocity and Sustenance}

Reciprocity is foundational to First Nations' relationships with the land. First Nations care for the land but the land also cares for them as clearly articulated by the northern Ontarian Chiefs and Councillors:

"We are one with the land, we depend on it to feed our families"

(Councilor for Kitchenuhmaykoosib Inninuwug (also known as Big Trout Lake First Nation), Sam McKay) [104] (p. 912)

"This land where I come from is very, very important ... We have an abundance of fish, wildlife, waterfowl and stuff, and as a result, the land is our social welfare system, and we would like to keep it that way."

(Chief of Weenusk First Nation, George Hunter) [113] (p. 956)

Similarly, in the semi-directed interviews from the land-use planning and EA sessions in Fort Albany First Nation, the land was mentioned as a source of food (e.g., moose, Alces alces; fish; waterfowl; caribou, Rangifer tarandus; berries; Labrador tea, Rhododendron groenlandicum), and referred to as "our grocery store" and "our garden" [102] (p. 5). The land was reported as being important to long-term food security: "People go up the river to go moose hunting, get their moose for the whole year ... That's our grocery site there" [102] (pp. 5-6). Further, there was a preference for wild foods by participants because of the social-cultural and health benefits associated with procuring and consuming food from the 
land [115]. However, threats to these food resources were identified, being related to mines and dams, destroying wildlife habitat and contaminating the food that they consumed.

Reciprocal and sustenance relationships between the land and Indigenous peoples has been widely reported for other northern hemisphere countries, such as Greenland, Sweden Finland and Russia [116]. In the southern hemisphere, the importance of land and "bush tucker" has been documented for Australian Indigenous peoples; bush tucker in Australia is essentially food from the land, water and sky [117]. Noteworthy, when 10 diabetic Australian Indigenous individuals partook in a traditional lifestyle for seven weeks, their clinical measures of blood glucose control greatly improved due to weight loss, increased physical activity, and a more traditional [118] and healthier diet $[119,120]$.

\subsubsection{Wellbeing}

The following are passages from the former Chiefs of Kashechewan First Nation and Fort Albany First Nation, the two First Nations downriver of the proposed Kabinakagami River Waterpower Project, to provide their perspectives of the land, and what happens when First Nations people are separated from the land, respectively.

"The land up north is our home. It's our lifeline, it's our bloodline of who we are. The land up north is not an untouched land. Our people, my ancestors, travelled that land. All over the area of my land, you can see sacred burial grounds... So it's not an untouched land; it's not a land that has been discovered... Without land, we will [not] be Cree people of James Bay... I want a future for them [grandchildren]. I want to teach them about the land that I grew up in, where my grandparents taught me."

(Chief of Kashechewan First Nation, Jonathon Solomon) [121] (p. 954)

"It was stated earlier that we're nomadic people, and the treaty gave us something really different. A lot of people are displaced [off the land]. The young people today don't know who they are. Their identity is lost. So you have a high rate of suicide. Those are the symptoms of the treaties and the policy-making of the governments."

(Chief of Fort Albany First Nation, Andrew Solomon) [122] (p. 953)

Land was identified as being central to Indigenous wellbeing and culture:

"The majority of our members are living in poverty ... yet despite all this I believe we are one of the wealthiest First Nations in Canada. We still have our language, our culture and we are still able to go out on our land and to engage in our traditional aboriginal practices."

(Chief of Attawapiskat First Nation, Theresa Hall) [123] (p. 981)

In Fort Albany First Nation, rebuilding Indigenous relationships with the land was identified as important, especially in the context of colonialism:

"Me, along with most community members, were ... a product of the residential school system ... While I was down south, I lost how to hunt and trap. But when I came back home, luckily my dad, my in-laws, were able to teach me back those- how to hunt, how to trap ... And we have to bring that [hunting and trapping skills] back... We have to keep that alive." [102] (p. 10)

"[Youth] learn about where they come from. You know, 'this is where my parents trapped, this is where my grandparents trapped, and this is important to us because I have a connection there.'" [102] (p. 10)

In short, land and being on the land was important for the transfer of Indigenous knowledge, and the preservation of Indigenous culture. By protecting the land, one is also protecting traditional subsistence activities that are of great importance, socially, culturally, and economically [115]. Further, in land use planning, precautionary measures are needed to ensure that future development does not unduly impact the land, the Ontario Cree, and their way of life [102]. To the point, the northern Quebec Cree assert that: "What you do to Eeyou Istchee (our land), you do to Eeyouch (our people)" [114] (p. 1). In other words, if you destroy the Cree homelands, you destroy the Cree people. Windsor and 
McVey [108] (p. 148) contend that: "The importance of place and sense of place to human well-being cannot be over-stated." They examined how hydroelectric dam construction in the homelands of the Chelatta T'En, British Columbia, Canada, resulted in a loss of the sense of place for the Chelatta T'En who were forcibly removed from their homelands. Negative impacts on the Chelatta $T^{\prime} E n$ included damaged interpersonal relationships and loss of group identity; a replacement piece of land would not suffice because of the loss of interconnectedness, history, and culture [108]. In Ontario, First Nations women who were displaced from their home communities and social support networks because of residential school, report similar types of disconnection from families, communities, and culture [124].

The importance of on-the-land Indigenous cultural activities to health [125] and wellness [126] initiatives has been recognized, since potential impacts of Indigenous cultural activities go beyond physical health benefits, and-include wellbeing benefits. This has been reported for American Natives [127,128], the Maori people of New Zealand [129], and other First Nations people of Canada [130]. Recently published systematic reviews on the health-and-wellness impacts of traditional activities in Indigenous youth [131] and Indigenous adults [132] highlight the importance of land-based activities with respect to positive benefits for Indigenous peoples worldwide.

\subsection{Water}

\subsubsection{Sustenance and Travel}

Water is required for human survival, but it is not just the quantity of water that is important, the quality of water has to be considered. Quality of water is typically thought of in terms of contamination (biological and/or chemical) [133]. In the Far North region of Ontario, there was little to worry about with respect to water quality from natural sources:

"The Far north is First Nations land... We've got good, clean water and we can dip our cups into any of our river and creek systems without worrying."

(Chief of Weenusk First Nation, George Hunter) [113] (p. 956)

Unsurprisingly, the Albany River and its tributaries were viewed as sources of highquality drinking water [102]. The main threats to the quality of the water were identified as hydroelectric development and mining [102].

However, water quality was an issue in the near north of Ontario because of development:

"We worry about our water [because of pollutants] ... hydro dams ... They washed away our graveyards into the lakes, and yet development still happens ... Development, yes, but ... We have to come to some sort of conclusion on how we're going to develop our territories [sustainably] ... You [Government of Ontario] took us off our land. You took us away from our home so you can develop industry... The point is what? Destroying the lands, our rivers, our waters."

(Chief of Wahgoshig First Nation, David Babin) [134] (p. 955)

Being worried about water quality in relation to potential pollution from industrial and hydroelectric development can lead to behavioural changes as reported for northern Quebec Cree [133]. Moriarity et al. [133] showed that the First Nation Cree of Quebec consumed less tap water (and more bottled water) in their home community with this behaviuor being significantly associated with increased worry. Unfortunately, stress level indicators, such as salivary cortisol, were not measured in this study.

The Albany River and its tributaries were identified by the people of Fort Albany First Nation as an important transportation network: “This river, that's our highway, we call it. We go to Constance Lake from here to get something, up the river and moose hunting. We don't want any dams, like me, I don't want any dams on the river myself." [102] (p. 6). Similarly, Chief Jonathon Solomon of Kashechewan First Nation [121] (p. 954) states: "That is my highway; the river is my highway. The river is my area of hunting." Likewise, people from Constance Lake First Nation acknowledged the importance of the Albany River to 
the people downstream the potential hydroelectric development, for transportation and the carrying out of traditional pursuits:

"Some men from the reserve come down the river to set fish lines and give fish to Elders in the community... In the fall lots of moose hunters go down on Kabina River [the Kabinakagami River] ... for holidays; they don't care if they get their moose, some want to stay longer to enjoy the land and rivers: ... in summer at Mammattawa I met people from Ogoki and Fort Albany and Kashechewan going up the the Kabina River to visit relatives in Constance Lake... I want to say this river is very important to many people, specially the young people in the community of Constance Lake, they going to use this river for many years to come. It's heritage river... Let the river run free for next generation." (The Elder Joe Taylor of Constance Lake First Nation [59] (Appendix C7).

\subsubsection{Wellbeing}

Activities in the Albany River basin were described as being important not only for connecting to the land, but also for reinforcing social connections:

"I would say like once a guy needs time for himself they go in the bush, it's quite spiritual. Because you're lost, where are you going to go? When you're in the bush, you're not lost." [102] (p. 9)

"We go there, we go up the river for family outings ... Like we do that on maybe Mother's Day or Father's Day, take the whole family camping, geese there, roast over the fire." [102] (p. 9)

In a workshop for the Kabinakagami River Hydropower Project which included individual and group sessions with Constance Lake First Nation community members, specific questions were asked, including: "What are your values on the Kabinakagami River?" and "What are your thoughts (benefits, fears, concerns, etc.) on these Projects?" [59] (pp. 2-23). Recorded meeting minutes were said to be available in Appendix C4 [59], but nothing could be found in Appendix C4 related specifically to the environmental "value" question. Appendix C4 only contained the Kabinakagami River Project presentation, and a section entitled "Discussions with Members of Constance Lake First Nation" [59] (Appendix C4) which only included brief and limited "highlights" (e.g., "moose calve on islands between Site 8 Amisk and Site 7 Neekik"). Unfortunately, this "checkmark" type of approach is not what Indigenous leaders consider meaningful consultation, especially in the context of the duty to consult doctrine with respect to Indigenous peoples that has been entrenched in the Canadian legal system [44,70].

Canadian Inuit partake in a marine lifestyle governed by their codes of conduct; the water landscapes (water, sea ice, and land) have been described as being therapeutic, with on-the-water-and-land activities, such as hunting, fishing, and intergenerational transfer of knowledge related to wellbeing [135]. There was a connection to place not just space for the Inuit [135]. The importance of water landscapes to Indigenous wellbeing has been reported worldwide. For example, water landscapes are sacred to Australia's First Peoples and their wellbeing tied into the health of country [105]. In New Zealand, the Whanganui River (water, banks, and bed) was central to the Maori lives and provided water and food; the river was also a highway and their spiritual mentor $[136,137]$. In other words, the river was integral to Maori health and wellbeing; the Maori people and the river were indivisible [136,137].

\subsection{Devlopment}

\subsubsection{Past Experiences in the Region}

The balance between First Nations' stewardship and "next to invisible use" of the land (Special Envoy of Nishnawbe Aski Nation, Frank Beardy) [112] (p. 953) becomes unbalanced with unsustainable resource development activities. Near north Ontarian First 
Nations that have experienced resource development firsthand give warning to the Far North Chiefs of Ontario:

"[The Government of Ontario] ... polluted all south of 50 ... You want to go north of 50 now ... because you've ruined it here. I've warned the northern chiefs. I live south of the 50th parallel, and I've seen the behaviour... These people are here to protect their homelands that belong to them. It doesn't belong to Ontario."

(Chief of Chapleau Cree First Nation, Keeter Corston) [106] (pp. 955-956)

"European people have come here, and look what they've developed; they've developed a land of disaster... Our people are getting sick from all these industries that are coming around our territory ... I'm in the Timmins area, where development is very, very high. We've got the mining industry and the forest industry, where they leave a lot of pollutants behind."

(Chief of Wahgoshig First Nation, David Babin) [134] (p. 955)

Lastly, the Far North Cree Elders' focus group (Moose Factory, Ontario; [138]) laments: "what good is money when the land is ruined" and "nothing will replace the land". Thus, it is unsurprising that the Elders take a hardline stance with respect to development: "advice to our chiefs ... enough is enough. We will hold what is left out there and then we will fight for it ... our land is not for sale. It is not for sale. We want to keep that." (Elder of the Mushkegowuk Territory, northern Ontario, Gregory Koostachin) [139] (p. 958).

4.4.2. The Constance Lake First Nation Perspective on the Kabinakagami River Waterpower Project

It would be expected that Constance Lake First Nation as a co-proponent of the Kabinakagami River Waterpower Project would have been fully supportive and involved in all project activities. However, this was not the case due to a schism in the community. The results of the 17 August 2010 referendum held in Constance Lake First Nation by their Chief \& Council did not support the Kabinakagami River Project (see Table 2 for a chronology of events); however, Chief \& Council moved ahead with the project in spite of losing the referendum. In a letter dated 24 August 2010, sent to the Royal Canadian Mounted Police (RCMP)—Canada's national police force-a member of Constance Lake First Nation voiced concerns about the Kabinakagami River Hydro Projects:

"Today, we have developer coming to our community wanting to start hydro projects on our traditional territory and seeking our approval to start these projects. Daming the river will have an environmental impact on the river system, which will also have affect fish and wildlife ... we have use this river for our survival and we are not going to stop use it now. This river must be protected for future generation ... it will be a great disaster to built these four hydro projects on this river ... On August 17, 2010, we had a referendum to decide wheater or not to approve these four proposed hydro projects on our land ... the result was no vote to the projects ... I would like you to talk to hydro developer to stop harassing our people, in regard to the projects. I am writing this letter because our Chief is not listening to our concerns." [59] (Appendix C7, Anonymous, 2010) 
Table 2. Chronology of events related to the Kabinakagami River Waterpower Project in northern Ontario, Canada [59,80,140-142].

\begin{tabular}{|c|c|}
\hline Date & Event \\
\hline 2007-2008 & $\begin{array}{l}\text { Constance Lake First Nation Chief Arthur Moore \& Council and Northland Power Inc. had discussions } \\
\text { with respect to the development of hydroelectric power on the Kabinakagami River }\end{array}$ \\
\hline May 2009 & Green Energy Act (2009) passed. \\
\hline November 2009 & $\begin{array}{l}\text { Constance Lake First Nation and Northland Power Inc. formally agree to proceed with the } \\
\text { Kabinakagami River Waterpower Project. }\end{array}$ \\
\hline June 2010 & $\begin{array}{l}\text { The Ontario Ministry of Natural Resources provided a Site Information Package to Northland Power } \\
\text { Inc. whereby the Albany River First Nations, that is, Constance Lake, Fort Albany, and Kashechewan } \\
\text { were to be consulted. }\end{array}$ \\
\hline 17 June 2010 & $\begin{array}{l}\text { The Kabinakagami River Waterpower Project notification given to Fort Albany First Nation from } \\
\text { Constance Lake First Nation and Northland Power Inc. }\end{array}$ \\
\hline 17 August 2010 & $\begin{array}{l}\text { Constance Lake First Nation community referendum held about the Kabinakagami River Waterpower } \\
\text { Project. The result was } 105 \text { against and } 97 \text { votes for the project. }\end{array}$ \\
\hline December 2010 & $\begin{array}{l}\text { Constance Lake First Nation Chief \& Council asked Indian and Northern Affairs Canada (INAC) for an } \\
\text { opinion on the referendum: "the referendum could only be classified as an expression of interest. } \\
\text { INAC went on to say that ultimately the decision lies with the elected leadership of the First Nation, } \\
\text { acting in the best interest of their members. The letter concluded by saying that a vote under the Indian } \\
\text { Referendum Regulations is not a requirement in this case as this Project is situated off reserve." [59] } \\
\text { (pp. 2-21) }\end{array}$ \\
\hline February 2011 & $\begin{array}{l}\text { Constance Lake First Nation Chief \& Council moved ahead with the hydroelectric project, based on } \\
\text { INAC's letter. }\end{array}$ \\
\hline June 2011 & $\begin{array}{l}\text { A new Constance Lake First Nation Chief \& Council elected replacing the old Chief and } \\
\text { three Councillors. }\end{array}$ \\
\hline November 2011 & $\begin{array}{l}\text { Vote of non-confidence for new Chief Roger Wesley of Constance Lake First Nation by the majority of } \\
\text { the membership (Hydro Dam Petition with } 117 \text { members signatures) because: "Failed to honor and } \\
\text { respect the referendum that was held August, } 2011 \ldots \text { to approve or reject Northland Power proposal;" } \\
\text { and "Failed to recognize and respect community Elder's wisdom, knowledge and advice towards the } \\
\text { betterment of Constance Lake community" [59] (Appendix C7). }\end{array}$ \\
\hline November 2011 & $\begin{array}{l}\text { "At recent public meetings in Constance Lake the membership voted overwhelmingly in favour of the } \\
\text { project proceeding ... Since the petition was circulated, over half the signatories have come forward } \\
\text { and requested that their names be removed from the petition." [59] (Table 2.1) }\end{array}$ \\
\hline November 2011 & Provincial Notice of Commencement for the Kabinakagami Class EA. \\
\hline 6 December 2011 & First Public Information Centre meeting in Hearst, ON, for the Class EA. \\
\hline 14 December 2011 & $\begin{array}{l}\text { Federal Notice of Commencement for the Kabinakagami Waterpower River Project for the Screening } \\
\text { EA under the Canadian Environmental Assessment Act (1996). [84] }\end{array}$ \\
\hline 11 January 2012 & Second Public Information Centre meeting in Hearst, ON, for the Class EA \\
\hline 9 April 2012 & $\begin{array}{l}\text { The Draft Kabinakagami Waterpower River Project document that meets the requirements of both the } \\
\text { Environmental Report (OWA Class EA) and the federal Screening EA was completed. }\end{array}$ \\
\hline February 2012 & $\begin{array}{l}\text { The Draft Kabinakagami Waterpower River Project Environmental Report (Class EA) issued to Ontario } \\
\text { Agencies for comments. }\end{array}$ \\
\hline 13 April to 14 May 2012 & $\begin{array}{l}\text { The Draft Kabinakagami Waterpower River Project Environmental Report (Class EA) available for } \\
\text { 30-day Public Review. }\end{array}$ \\
\hline 11 May 2012 & $\begin{array}{l}\text { Chief A. Solomon of Fort Albany First Nation sends a request to Minster J. Bradley of the Ontario } \\
\text { Ministry of Environment to bump-up the Kabinakagami Class EA to a more comprehensive } \\
\text { Individual EA. }\end{array}$ \\
\hline
\end{tabular}


Table 2. Cont.

\begin{tabular}{cl}
\hline \multicolumn{1}{c}{ Date } & \multicolumn{1}{c}{ Event } \\
\hline 12 July 2012 & $\begin{array}{l}\text { Letter to Chief A. Solomon of Fort Albany First Nation from Minster J. Bradley stating that the } \\
\text { bump-up request should be made during the final Environment Report's 30-day Public Review period. }\end{array}$ \\
\hline July 2012 & $\begin{array}{l}\text { The federal Screening EA for the Kabinakagami Waterpower River Project no longer required under } \\
\text { the newly passed Canadian Environmental Assessment Act [84]. }\end{array}$ \\
\hline 23 January 2012 & The Final Kabinakagami Waterpower River Project Environmental Report (Class EA) completed. \\
\hline 5 February 2013 & The Final Class EAS Report available for 30-day Public Review. \\
\hline 2014 & $\begin{array}{l}\text { Chief R. Knapaysweet of Fort Albany First Nation sends a request to Minster J. Bradley to bump-up the } \\
\text { Class EA to a more comprehensive Individual EA. }\end{array}$ \\
\hline & $\begin{array}{l}\text { "Based upon the most current review of project costs and the OPA [Ontario Power Authority } \\
\text { confirming in January 2014 that PPA [Power Purchase Agreement] prices would not be escalated with } \\
\text { inflation ... the Kabinakagami hydro projects no longer meet Northland's policy requiring that they be } \\
\text { 'highly certain' of being developed and constructed." As a result, \$5.2 million of previously deferred } \\
\text { development costs related to the Kabinakagmi hydro projects were written off during the first quarter } \\
\text { of 2014. Management is exploring its options for the project." [140] (p. 24). }\end{array}$ \\
\hline $\begin{array}{l}\text { Ontario Rivers Alliance made a bump-up request for the Kabinakagami Waterpower River Project and } \\
\text { has no decision on their request [141]. }\end{array}$ \\
$\begin{array}{l}\text { The last step in the OWA Class EA process is the "Issue Statement of Completion." There is no } \\
\text { evidence that this step has been completed on the Ontario Waterpower Association's website or the } \\
\text { Northland Power website [142]. }\end{array}$ \\
\hline 2017
\end{tabular}

In December 2010, Indian and Northern Affairs Canada offered an opinion that the referendum of 17 August 2010 was outside their jurisdiction because the project was on Constance Lake First Nation traditional territory, not reserve land (Table 2). Thus, in February 2011, Constance Lake First Nation Chief \& Council moved forward on the hydroelectric project based on the Indian and Northern Affairs Canada letter.

In a follow-up letter to the RCMP, dated 9 February 2011, by the same member of Constance Lake First Nation who voiced concerns in the earlier letter about the Kabinakagami River Hydro Project, s/he provided an update of the situation and concerns about violence in the community:

"[RCMP] never responded my letter ... On Monday February, 07, 2011, at general membership meeting, the chief and with three other councilors informed the people, that the referendum that was held in August, 2010, is not valid, because the vote was very close; the result was 105 members were against and 79 were fore the hydro project. At February, 08, 2011 meeting some band members became very angry at chief and three council members when informed that chief and council signed the proposed hydro project agreement, without the membership consent. Today, the chief and three councilors are under heavy fire; some of us are afraid this issue could escalate to violent among our own people; elders see this happening should Northland Power Co. continue to intervene with our affairs ... we want peace in our homeland, we do not need civil arrest ... I asking you to communicate with Northland Power about our concerns toward the project." [59] (Appendix C7, Anonymous, 2011)

In June 2011, a new Constance Lake First Nation Chief \& Council were voted in by the community; on 21 November 2011, there was a vote of non-confidence for the new Chief Roger Wesley by the majority of the membership. The Hydro Dam Petition had 117 community member signatures. There was a petition because the new Chief: "Failed to honor and respect the referendum that was held August, 2011 ... to approve or reject Northland Power proposal;" and "Failed to recognize and respect community Elder's wisdom, knowledge and advice towards the betterment of Constance Lake community" [59] (Appendix C7). The Hydro Dam Petition stated: "We the Constance Lake First Nation want 
nothing to do with the Hydro Dam Project because it will kill our wildlife and be a negative impact on our community. Think about your children and their children's children." [59].

An Open House was held at the Constance Lake First Nation Community Centre on 8 December 2011, and although 40 people attended, only two left comment sheets. The issues raised during the Open House included concerns about negative impacts on habitat, fish, wildlife, and the First Nations way of life. Also on this date, the spokesperson for the Elders and people of Constance Lake First Nation released a statement [59] (Appendix C7):

"I am totally oppose Northland hydro development project on Kabinakagami River. This river is a heritage for Constance Lake First Nation people for thousands of years ... The hydro project will have an ecological impact on humans, fish $\mathcal{E}$ wildlife, insects and bids ... its causes a division on our people ... referendum [held] ... Unfortunately, the results of the vote was not honoured by the previous Chief and some Council members ... Again on November, 2011 there was a petition circulating community opposing the hydro project over 120 signatures were collected. Still present Chief is not responding to the petition. We value the river... This is our river it [economic benefits from the hydro project] will not solve the community social problems that were facing today. We say no to the proposed project, it will cause significant adverse environment."

At the Open House on 14 January 2012, a total of nine people attended and one comment sheet was left that asked "Will the Project have effects on downstream First Nations (e.g., Fort Albany First Nation)?" [59] (Table 2.5). Lastly, an anonymous Elder [59] (Appendix C7, pp. 1-6) left an insightful commentary on the Kabinakagami River Waterpower Project:

"Hydro electricity is perceived to a clean form of energy ... Almost all Hydro electric projects relied on the impoundment of water flow ... The flooded lands is no longer... habitat for terrestrial animals, the flooded lands also disrupt the ground water level in the vicninity along to the rivers ... water levels in the impoundment will rise and fall seasonally ... destabilizes the shore line ... bacteria [changes] ... inorganic mercury into biologically actives ... methylmercury ... fish which concentrate the mercury in their flesh ... Human that eat the fish will accumulate high concentration of mercury ... The Northern [Quebec] Cree nation known first hand experienced the consequences of massive flooded lands ... Native spiritual and ecological knowledge has intrinsic values ... Mutually enriching the native and scientific ways of knowing about nature each traditional aspect has much to learn from each other."

Clearly, most Constance Lake First Nations value the land and the Kabinakagami River, and want to preserve it for future generations, but there is still a group in their community that is in a leadership position that is pro-hydroelectric development.

4.4.3. The Downriver Perspective of the Kabinakagami River Waterpower Project: Fort Albany First Nation

Historically, the rivers and waterways of Ontario were the primary means of transportation and substantial source of resources for the Indigenous communities. Thus, it comes as no surprised that Fort Albany First Nation opposed hydroelectric development on the Albany River, where they have had no input:

"We can't stress the importance of ... [the Kabinakagami Project] and its potential negative impacts to our community in strong enough terms. The participants at the community meeting of 10 May 2012 highlighted the relationship between the land, the river and our wellbeing over past, current and future generations. It is this connection that requires us to take an active role in this proposed development and ensure a proper EA process is followed; one that includes our knowledge and influence."

(Chief of Fort Albany First Nation, A. Solomon) [99] (p. 1)

Taking into account the discussions that Fort Albany First Nation and Kashechewan First Nation had with the Ontario Power Generation and the Government of Ontario, with 
respect to the potential hydroelectric sites of Hat Island and Chard River in the Albany River Basin [76], the identified study area of the Kabinakagami River Waterpower Project EA [143] was restrictive and should have included Fort Albany and Kashechewan First Nations: "since they are downstream from the project and have the potential to be impacted by the project" (Chief of Fort Albany First Nation, A. Solomon) [99] (p. 2). There were also concerns with respect to water quality, fish passage, river ice, and water temperature; this was compounded by the inadequacy of the Cumulative Effects Assessment conducted [99] that needed to be addressed in the Kabinakagami River Waterpower Project EA [143]. The Chief of Fort Albany First Nation, A. Solomon [99] (p. 4) remarks:

"An overall observation is the lack of scientific evidence, modelling or comparative project analysis conducted as part of this Class environmental assessment [i.e., the Kabinakagami River Waterpower Project EA]. The overwhelming majority of claims made appear to be based on best professional judgement, the weakest type of prediction available to environmental assessment practitioners. This inevitably results in the impossibility of verifying the accuracy of predictions and the efficacy of mitigation measures."

Chief A. Solomon ends his request letter to the Minster of the Ontario Ministry of Environment, J. Bradley, to bump-up the Kabinakagami Waterpower River Project's Ontario Water Association's Class EA to a more comprehensive Individual EA, with the following paragraph:

"In summary, we want to return to the importance of this project to our people and our spiritual connection to the land and the Albany watershed. Prior to first contact with settlers, our footprint on the land was minimal and, for the most part, the land remained unspoiled. The women of our First Nation are particularly concerned with this proposal as they are considered the water keepers. During the community meeting of 10 May 2012, this point was made clear: the connection between the land, water, and life is integral to our people. And this is why we are taking this proposal seriously and have the full expectation that we will be properly consulted and our Traditional Knowledge will be collected and influence the decision on this project and future projects in the watershed. As already stated, we request that you require the proponent to carry out an Individual EA of this project." [99] (p. 10)

Since Chief Solomon's bump-up request letter was submitted during the Draft Kabinakagami Waterpower River Project Environmental Report's 30-day public review, he was informed by Minster Bradley that the request for bump-up should be made during the Final Kabinakagami Waterpower River Project Environmental Report's 30-day public review (see Table 2 for a chronology of events).

Thus, Chief A. Solomon's successor in Fort Albany First Nation, Chief R. Knapaysweet, subsequently sent in another bump-up request letter on behalf of the community [100] during the Final Kabinakagami Waterpower River Project Environmental Report's 30-day public review (Table 2). Chief Knapaysweet [100] (p. 1) reiterates that "there is a long history of Fort Albany First Nation using that area for subsistence activities." It is for this reason that Chief Knapaysweet identifies project effects on the fish population are of importance and must be addressed in a meaningful way based on science and Indigenous knowledge (see Table 3 for details). 


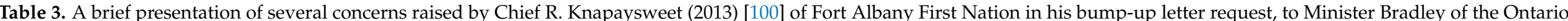

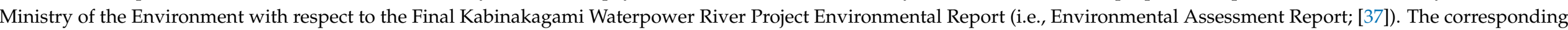
text in the Final Kabinakagami Waterpower River Project Environmental Report that Chief Knapaysweet referred to in his letter, is also presented.

\section{Comments Made by Chief Rex Knapaysweet (2013) of Fort Albany First Nation}

[Unsubstantiated claims are made in the absence of data, leading to] the impossibility of verifying the accuracy of predictions and the efficacy of mitigation measures. This is unacceptable, especially for a project in unmanaged waterways in a location that is not data-rich. In this regard, the proponent argues that (p. 6) [see next column over]

But then contradicts itself on a number of occasions (p. 6): [see next column over]

This means the proponent does not know what will happen to fish populations as a result of this project, and are basing their qualitative "prediction" on their so called expert opinion. In other words, this project does not have predictable effects, as claimed by the proponent (p. 6).

Another similar example in regards to how this project does not have predictable effects (p. 6): [see next column over] These examples highlight how a number of the effects of this project are not predictable, and using expert opinion as the main "source of information to make decisions about potential impacts and relative significance of impacts is inadequate and unacceptable. mpact prediction should be grounded in the evidence presented during the assessment and formulated in a way that can be tested and used for monitoring and follow-up. [p. 6]

[Furthermore] having water flow data only from 1951 to 1986 raises a number of concerns ... the predictions are based on out-of-date data for the Kabinakagami River ... [and] during ... community meeting on 10 May $2012 \ldots$ a number of elders indicated concern with recen changing water flows in this watershed system, likely changes resulting from our changing climate, an issue poorly addressed ... an MOE letter dated March 16, $2012 \ldots$ stated "we believe there should be a fuller recognition and consideration of the implications of climate change over the operational life of the facilities". (p. 7)

In addition, the developer claims that the (p. 7) [see next column over]

This is an absurd statement based on no scientific evidence or on any of the current climate change trends identified in the scientific literature. (p. 7)

Moreover, under "probability of effect", the developer claims that (p. 7) [see next column over]

The probability of climate change happening is not unknown, buth. What is unknown is how climate change will affect this project,

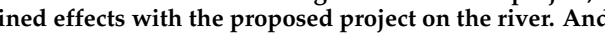
this, again, goes against the proponent's claims that this hydro project has predictable and mitigable effects. (p. 7)

\section{Fish passage}

The proponent makes clear that fish passage will not be used as it was determined by them that it was not feasible $\ldots$ There has been successful examples of fish passage for the fish population present in this area (e.g., brook trout and lake sturgeon) such as 'vertical slo ishway' [85] and 'spiral fish ladder' [86], therefore the argument ... is not substantiated by the scientific literature ..

In addition, the proponent claims that (p. 8) [see next column over]

We .

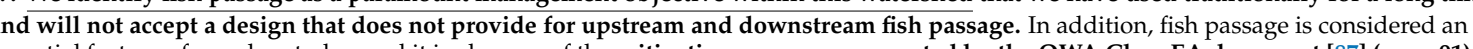
. well known to have severe impacts on several sturgeon traditionally used the Albany and many of its tributaries and are absolutely opposed claiming, (p. 8) ... Fort Albany First Nation ... have
Corresponding Text in the Final Kabinakagami Waterpower River Project Environmental Report (Hatch, 2013) Referred to by Chief Knapaysweet

Small hydro Projects, particularly strict run-of river projects such as the proposed, do have predictable and mitigable effects (page 2-10),

No scientific evidence is available regarding the adverse effects of blockage of fish movements at this particular location on the Kabinakagami River (page 2-12).

Methyl mercury production due to initial head pond inundation is anticipated to be returned to natural

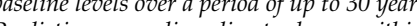

Prions regarding climate change within the Study Area are not known to be available to accurately predict occur within the timeframe of expected duration of eleonted methyl mercury production within the Project head ponds (page 2-33).

Hydrology Review (Appendix D)

effects of climate change interacting with the project may be reversible if climate change started reversing

The probability of climate change occurring within the lifetime of the Project to the degree where effects on environmental may occur (sic) due to operations of the Project is Unknown. [3,7-23] 


\section{Green for Whom?}

\subsection{The Kabinakagami River Waterpower Project}

When addressing the titular question of green for whom, typical hydroelectric development is not green, insofar as impacts to the environment are mostly negative and oftentimes quite severe. It was consistently mentioned by the Chiefs of northern Ontario that First Nations have an inherent right and responsibility to care for the land, leaving the land seemingly untouched, and with reciprocity the land will care for them. Clearly, this is not the case with hydroelectric projects. Even though run-of-the-river hydroelectric facilities have been espoused as being more benign in their impact with respect to the environment than typical hydroelectric developments employing larger dams in their design, in reality, this is not the case. Run-of-the-river hydroelectric facilities still require in-river barriers that fragment the river system, impoundment of water, cause fish morbidity and mortality when the fish pass through the turbines. It should be emphasized that no fish passages were included in the proposed Kabinakagami River Waterpower Project's designs for the run-of-river power-generation facilities. The lack of fish passages was duly noted by Fort Albany First Nation Chief Knapaysweet, in his request for a bump-up, because fish are of great importance to the First Nations' way of life (Table 3).

Despite river habitat fragmentation being covered extensively in Chief Knapaysweet [100] bump-up letter request (Table 3), one issue that was not covered was the potential non-riverine habitat fragmentation caused by construction of hydroelectric transmission corridors. Fragmentation of the environment by transmission-line corridors has been reported in the literature $[144,145]$. This issue will be briefly addressed because access to the power grid and end source user is a requirement of hydroelectric power generation, and it is relevant to answer the question: green for whom? The James Bay transmission corridor will be utilized as an example because this transmission line is relatively recent and is located in the Far North of Ontario, in the western James Bay region. In a study by McEachren et al. [81], it was found by utilizing Indigenous knowledge that due to the erection of the transmission line corridors, significant impacts on waterfowl migration directly impacted western James Bay Cree's ability to partake in waterfowl harvesting activities. These impacts were non-uniform and dependent on the geospatial location of the peoples' camps along the hydroelectric corridor. Although the construction of the proposed transmission line for the Kabinakagami River Waterpower Project would probably only impact traditional pursuits for the Constance Lake First Nation people, this may not be the case because the new transmission corridor fragments the terrestrial and aerial environment and could change migration patterns not only for waterfowl but also moose.

Of great importance to the First Nations subsistence diet, in the proposed Kabinakagami River Project, the concentration of methyl mercury in different species of reservoir fish were predicted to increase 1.7-2.0-fold above baseline concentrations [146]. Downstream, fish mercury concentrations may increase, but "validated predictive models do not exist yet to predict peak fish $\mathrm{Hg}$ concentrations downstream or the distance downstream that increases may occur" [146] (p. 30). Elevated levels of mercury in fish were expected to persist in piscivorous fish approximately 30 years [146] (p. 30). Although mercury bioaccumulation in fish has been reported to return to background levels in most (but not all) species of fish 30-years post-impoundment, this still means that generations of First Nations people would not be consuming the mercury-contaminated fish, as mercury is a known neurotoxin. Further, generations of First Nations people would not be able to participate in their traditional pursuits related to fishing that have benefits beyond food procurement and consumption; this includes intergenerational transference of knowledge while on the land, and social and cultural interactions [147]. The northern Quebec Cree are a typical example of the negative impacts of hydroelectric projects; mercury contamination of fish is still an issue, and the recovery of traditional pursuits is a work in progress [125,148].

An important factor when examining the question, green for whom, is determining the geospatial scale. In the political deliberations in the Ontario Legislative Assembly with 
respect to the Green Energy Act (2009), the importance of mitigating climate change by reducing greenhouse gas emissions through green energy was consistently mentioned by the Members of Provincial Parliament. The Ontario Minister of Energy and Infrastructure, G. Smitherman [22] (p. 4952) wanted Ontario to "join the ranks of global green power leaders like Denmark, Germany and Spain." The Government of Ontario had only a global perspective with respect to green energy generation; this is to say that the decreased emissions of greenhouse gases would help combat global warming, but little attention was given to potential local-regional effects of green energy generation. Global warming is an important issue and needs to be addressed, but the vulnerable Indigenous populations should not have to bear the brunt of the burden.

In addition, since most potential hydroelectric development sites were located in northern Ontario [70], southern Ontarians would have little opportunity to see the impacts of hydroelectric development in northern Ontario, but would reap the benefits, while the First Nations in northern Ontario would bear the burden of the development. To southern Ontarians, hydroelectric power generation is green because hydroelectric power generation typically emits less greenhouse gases than carbon-based sources, and southern Ontarians would feel like the Province of Ontario was contributing to the fight against climate change.

In the case study, Northland Power Inc. as a co-proponent of the Kabinakagami River Waterpower Project would reap financial benefits from the green energy project, but bear none of the environmental impacts associated with the project. Northland Power Inc.'s costs would only be financial. In contrast, Constance Lake First Nation, as a co-proponent of the Kabinakagami River Waterpower Project with Northland Power Inc. (Toronto, ON, Canada) would reap financial benefits and bear the environmental impacts associated with the run-of-the-river hydroelectric development. As these impacts would not be trivial, there was a schism in the community of Constance Lake First Nation for those who supported First Nations traditional values, and those who put resource development and associated monetary benefits first. The way that the referendum result was mishandled ended any chance of an intracommunity reconciliation. The majority of Constance Lake First Nation community did not view the Kabinakagami River Waterpower Project as being green with minimal effects on the environment and their way of life.

Geospatial location is also important, regionally, with respect to hydroelectric projects. Fort Albany First Nation and Kashechewan First Nation being downstream of the Kabinakagami River Waterpower Project would not reap any financial benefits from the project, but would bear the downstream costs associated with the development. This is why the downstream First Nations wanted a more comprehensive Individual EA done rather than a Class EA. Ideally, no development would have been the best option, but being informed so late in the EA process (Table 2), the next best option was the bump-up letter request (Table 3). Although run-of-river hydroelectric projects are smaller in scale compared to hydroelectric projects that incorporate large dams, as Chief Knapaysweet [100] points out in his bump-up letter: it is the cumulative effects of not only the four run-of-river facilities described in the Kabinakagami River Waterpower Project, but also the two run-of-river facilities slated for future consideration. Furthermore, the proposed Chard River and Hat Island hydroelectric facilities proposed for the Albany River by Ontario Power Generation must be considered in any cumulative effects predictions [100]. Development projects in northern Ontario must not be dealt with on a project-by-project basis; they must be examined strategically as a group using a regional approach.

\subsection{Is Strategic Planning the Way Forward?}

In the Government of Canada-commissioned expert panel review of the Canadian environmental assessment process, there was extensive consultation across Canada; strategic and regional assessment approaches were commonly mentioned by experts, nongovernmental representative, Indigenous peoples, and the public as the potential way forward leading to more sustainable development projects [149]. In fact, the recently passed Impact and Assessment Act [150] contains sections discussing the Canadian strate- 
gic and regional assessment processes; thus, there is movement towards strategic planning in Canada with respect to development projects, including hydropower generation in northern Canada.

Globally, strategic-hydropower-dam planning has been proposed for the Amazonian basin to reduce greenhouse gas emission; there already exists 158 dams with 351 planned [151]. Basin-scale dam planning could reduce emissions-by taking into account that proposed Amazonian upland dams have an emission profile similar to solar and wind energy - while some lowland dams may exceed emissions from fossil-fuel-power plants [151]. Almeida et al. [151] suggest that this strategic planning approach could be adapted to other major river basins of the world (e.g., Congo, Mekong, Ganges, and Yangtze) where hydropower is rapidly developing. However, Kahn et al. [7] (p. 6063) mentions "False Shades of Green" in reference to Brazilian Amazonian hydroelectric development because of the significant local environmental and social impacts (e.g., displacement of rural and/or Indigenous communities; habitat fragmentation; loss of ecosystem services). Nonetheless, strategic dam planning may be a way to decrease emissions, while also lessening social and ecological impacts [151].

\section{Conclusions}

Worldwide, many countries have developed initiatives to develop certification standards for green electricity and green labelling of hydroelectric power generation [55], but it must always be remembered that calling something green does not make it so, and that the green moniker is mostly attached from a non-Indigenous political perspective. Hydroelectric power generation has negative impacts on the environment, this is not conjecture, it is fact, from both Indigenous and scientific perspectives. To label hydroelectric power green is a misnomer because of the extensive fragmentation of the aquatic, terrestrial, and aerial spaces that occur and its impact on biota. Only from a political perspective, such as the Green Energy Act (2009), can hydroelectric power generation ever be green because, as it has been shown, hydroelectric power is not inherently green. Renewable? Yes, but not green from any other perspective. Perhaps hydroelectric power should be rebranded as a lowcarbon-renewable system in temperate regions, as this designation would more adequately describe hydroelectric power generation from both scientific and Indigenous perspectives. Furthermore, when the social benefits of green energy are touted: "to improve human welfare, reduce energy related risks, social inequalities and poverty, promote intergenerational equality, and foster new opportunities for human development" [1] (p. 1285), it must be emphasized that these social benefits are typically for the non-Indigenous populations.

Importantly, it must be emphasized that the downstream First Nations on the Albany River are not against development per se:

"We are not against development [but it is rarely a partnership taking into account a First Nations' perspective]. All we're saying is, we continue to live in poverty while the province gets wealthier and richer ..." (Chief of Kashechewan First Nation, Jonathon Solomon) [121] (p. 954)

What these First Nations would like to see is a reciprocal relationship that also respects their worldview. Otherwise, a situation will exist, whereby reconciliation will be difficult:

"The Creator gave me a beautiful garden to watch and maintain. I was told to take from it only what I needed to survive. The Creator has also given the white man his own garden to watch and maintain. The white man came and destroyed the garden I was told to care for. How would the white man feel if we had gone and destroyed his garden? What would happen to us? We'd be put into jail and called criminals. So ask yourself who has committed the crime?"-Chisasibi elder, speaking about the La Grande Hydroelectric Project [114] (p. 1)

At present, the green for whom question is particularly relevant in Ontario where the recently passed COVID-19 Economic Recovery Act (2020) [152] has streamlined (or exempted) hydroelectric projects with respect to the EA process, thereby bypassing Ontario's legal 
duty to consult with Indigenous peoples [44]. Further, a Government of Ontario discussion paper described how clean technologies will enable a speedy economic recovery from COVID-19, while reducing greenhouse gas emissions [153]. Likewise, the Government of Canada identified clean power and technologies (which includes hydroelectric power) as having been important during the COVID-19 pandemic, and that clean energy will be an important avenue for growth in the future $[154,155]$. Similarly, on the world stage, a recently released Organization for Economic Co-operation and Development discussion paper mentioned the "greening" of the COVID-19 economic recovery, and referred to lessons learned from the past, in particular the financial crisis of 2008 [2]. While these two events are separated by more than a decade, they share many parallels with respect to how they are affecting modes of energy production. At the time, it was emphasized that green energy would be the saving grace from financial ruin [44]; now, countries are putting forth policies based on COVID-19 Recovery that follows a similar approach. Around the world, many countries, and scholars have begun to realize that while there have been many missteps along the way, the COVID-19 recovery that we will go through is an opportunity [16] - one that must not be squandered. This is an opportunity to remake and reimagine how hydropower, and sustainable energy production as a whole, is conducted $[156,157]$. COVID-19 has worn away at the old system and it has started to show its cracks [15], but amidst this pandemic and the slowed hydropower sector [158], the world has the opportunity to critically address these shortcomings. If nothing else, the existence of the pandemic has made us more aware of what necessary actions must be taken and how they must be taken in the context of the pandemic [15]. Without fail, the COVID-19 green energy recovery is coming, and we must be ready with brick and mortar in-hand-these will be the foundations for the next decade of potentially sustainable endeavours.

Author Contributions: S.R.J.T. worked on all aspects of the manuscript. D.D.P.M. and S.Q. supervised the writing, review, and editing of the manuscript. All authors have read and agreed to the published version of the manuscript.

Funding: This research was funded by Social Sciences and Humanities Research Council of Canada. grant number 435-2016-135.

Acknowledgments: We thank the reviewers for their constructive comments that improved the manuscript.

Conflicts of Interest: The authors declare no conflict of interest. The funders had no role in the design of the study; in the collection, analyses, or interpretation of data; in the writing of the manuscript, or in the decision to publish the results.

\section{References}

1. Mundaca, L.; Neij, L.; Markandya, A.; Hennicke, P.; Yan, J. Towards a Green Energy Economy? Assessing policy choices, strategies and transitional pathways. Appl. Energy 2016, 179, 1283-1292. [CrossRef]

2. Agrawala, S.; Dussaux, D.; Monti, N. What policies for greening the crisis response and economic recovery? Lessons learned from past green stimulus measures and implications for the COVID-19 crisis. OECD Environ. Work. Pap. 2020. [CrossRef]

3. Tsuji, S.R.J. Fiduciary Responsibility and the Green Energy Act, 2009 (Ontario, Canada). Environ. Justice 2020, 14, 76-85. [CrossRef]

4. Bhowmik, C.; Bhowmik, S.; Ray, A.; Pandey, K.M. Optimal green energy planning for sustainable development: A review. Renew. Sustain. Energy Rev. 2017, 71, 796-813. [CrossRef]

5. Omer, A.M. Green energies and the environment. Renew. Sustain. Energy Rev. 2008, 12, 1789-1821. [CrossRef]

6. Deemer, B.R.; Harrison, J.A.; Li, S.; Beaulieu, J.J.; DelSontro, T.; Barros, N.; Bezerra-Neto, J.F.; Powers, S.M.; Dos Santos, M.A.; Vonk, J.A. Greenhouse Gas Emissions from Reservoir Water Surfaces. A New Global Synthesis. BioScience 2016, 66, 949-964. [CrossRef] [PubMed]

7. Kahn, J.R.; Freitas, C.E.; Petrere, M. False Shades of Green: The Case of Brazilian Amazonian Hydropower. Energies 2014, 7, 6063-6082. [CrossRef]

8. Wüstenhagen, R.; Markard, J.; Truffer, B. Diffusion of green power products in Switzerland. Energy Policy 2003, 31, 621-632. [CrossRef]

9. Markard, J.; Truffer, B. The promotional impacts of green power products on renewable energy sources: Direct and indirect eco-effects. Energy Policy 2006, 34, 306-321. [CrossRef] 
10. Bratrich, C.; Truffer, B.; Jorde, K.; Markard, J.; Meier, W.; Peter, A.; Schneider, M.; Wehrli, B. Green hydropower: A new assessment procedure for river management. River Res. Appl. 2004, 20, 865-882. [CrossRef]

11. Moran, E.F.; Lopez, M.C.; Moore, N.; Müller, N.; Hyndman, D.W. Sustainable Hydropower in the 21st century. Proc. Natl. Acad. Sci. USA 2018, 115, 11891-11898. [CrossRef] [PubMed]

12. Keating, M.F. International political economy and the global governance of hydroelectric dams. In Handbook of the International Political Economy of Energy and Natural Resources; Edward Elgar Publishing: Warwick, UK, 2018; pp. 199-213. Available online: https:/ / EconPapers.repec.org/RePEc:elg:eechap:15812_14 (accessed on 4 August 2021).

13. U.S. Geological Survey. Hydroelectric Power Water Use. Available online: https://www.usgs.gov/special-topic/waterscience-school/science/hydroelectric-power-water-use?qt-science_center_objects=0\#qt-science_center_objects (accessed on 4 August 2021).

14. International Hydropower Association. 2021 Hydropower Status Report: Sector Trends and Insights. 2021. Available online: https: / /assets-global.website-files.com/5f749e4b9399c80b5e421384/60c37321987070812596e26a_IHA20212405-statusreport-02_LR.pdf (accessed on 4 August 2021).

15. Brosemer, K.; Schelly, C.; Gagnon, V.; Arola, K.L.; Pearce, J.M.; Bessette, D.; Olabisi, L.S. The energy crises revealed by COVID: Intersections of Indigeneity, inequity, and health. Energy Res. Soc. Sci. 2020, 68, 101661. [CrossRef] [PubMed]

16. Maniatis, K.; Chiaramonti, D.; van den Heuvel, E. Post COVID-19 Recovery and 2050 Climate Change Targets: Changing the Emphasis from Promotion of Renewables to Mandated Curtailment of Fossil Fuels in the EU Policies. Energies 2021, 14, 1347. [CrossRef]

17. Cooke, F.M.; Nordensvard, J.; Saat, G.B.; Urban, F.; Siciliano, G. The Limits of Social Protection: The case of hydropower dams and indigenous Peoples' Lands. Asia Pac. Policy Stud. 2017, 4, 437-450. [CrossRef]

18. Tsuji, S.R.J. Indigenous Environmental Justice and Sustainability: What Is Environmental Assimilation? Sustainability 2021, 13, 8382. [CrossRef]

19. Grill, G.; Lehner, B.; Thieme, M.; Geenen, B.; Tickner, D.; Antonelli, F.; Babu, S.; Borrelli, P.; Cheng, L.; Crochetiere, H.; et al. Mapping the world's free-flowing rivers. Nature 2019, 569, 215-221. [CrossRef]

20. Opperman, J.J.; Baruch-Mordo, S.; Carvallo, J.P.; Kammen, D.; Kiesecker, J.; Weber, C. Sustaining the Last Rivers: The Renewable Revolution Could Keep Dams Off the World's Remaining Free-Flowing Rivers. Am. Sci. 2019, 107, 302. [CrossRef]

21. Bill 150. Green Energy and Green Economy Act, 2009, S.O. 2009, c. 12. Available online: https://www.ontario.ca/laws/statute/ s09012 (accessed on 4 August 2021).

22. Smitherman, G. Official Report of Debates of the Legislative Assembly (Hansard). Available online: https://www.ola.org/sites / default/files/node-files/hansard/document/pdf/2009/2009-02/house-document-hansard-transcript-1-EN-23-FEB-2009_L1 12.pdf (accessed on 23 July 2021).

23. Green Energy Act (2009), S.O. 2009, c. 12. (Ontario, Canada). Available online: https://www.ontario.ca/laws/statute/09g12 (accessed on 4 August 2021).

24. Colle, M. Ontario, Legislative Assembly of Ontario. 9 March 2009 (Mr. Mike Colle, LIB). In Proceedings of the Legislative Assembly of Ontario, First Session, 39th Parliament, 9 March 2009. p. 5336. Available online: https:/ / www.ola.org/sites/default/files/nodefiles/hansard/document/pdf/2009/2009-03/house-document-hansard-transcript-1-EN-09-MAR-2009_L120.pdf (accessed on 23 July 2021).

25. Eyamie, L. Ontario, Standing Committee on General Government (Hansard). In Proceedings of the Legislative Assembly of Ontario, First Session, 39th Parliament, 16 April 2009. p. 570. Available online: https:/ /www.ola.org/sites/default/files/nodefiles/hansard/document/pdf/2009/2009-04/committee-transcript-1-EN-16-APR-2009_G024.pdf (accessed on 4 August 2021).

26. Fraser, B. Ontario, Standing Committee on General Government (Hansard). In Proceedings of the Legislative Assembly of Ontario, First Session, 39th Parliament, 15 April 2009. p. 530. Available online: https://www.ola.org/sites/default/files/nodefiles/hansard/document/pdf/2009/2009-04/committee-transcript-1-EN-15-APR-2009_G023.pdf (accessed on 4 August 2021).

27. Schnare, M. Ontario, Standing Committee on General Government (Hansard). In Proceedings of the Legislative Assembly of Ontario, First Session, 39th Parliament, 15 April 2009. pp. 494-495. Available online: https:/ /www.ola.org/sites/default/files/nodefiles/hansard/document/pdf/2009/2009-04/committee-transcript-1-EN-15-APR-2009_G023.pdf (accessed on 4 August 2021).

28. Broten, L. Ontario, Official Report of Debates of the Legislative Assembly (Hansard). In Proceedings of the Legislative Assembly of Ontario, First Session, 39th Parliament, 24 February 2009. p. 5013. Available online: https://www.ola.org/sites/default/files/ node-files/hansard/document/pdf/2009/2009-02/house-document-hansard-transcript-1-EN-24-FEB-2009_L113.pdf (accessed on 4 August 2021).

29. Smitherman, G. Ontario, Standing Committee on General Government (Hansard). In Proceedings of the Legislative Assembly of Ontario, First Session, 39th Parliament, 8 April 2009. pp. 411-412. Available online: https://www.ola.org/sites/ default/files/node-files/hansard/document/pdf/2009/2009-04/committee-transcript-1-EN-08-APR-2009_G021.pdf (accessed on 4 August 2021).

30. Stevenson, M. Indigenous knowledge in environmental assessment. Arctic 1996, 49, 278-291. [CrossRef]

31. Cruikshank, J. Legend and Landscape: Convergence of Oral and Scientific Traditions in the Yukon Territory. Arctic Anthropol. 1981, 18, 67-93.

32. Gamble, D. The Berger inquiry: An impact assessment process. Science 1978, 199, 946-952. [CrossRef] 
33. WCED. World Commission on Environment and Development. In Our Common Future; Oxford University Press: Oxford, UK, 1987.

34. United Nations. Agenda 21: The United Nations Programme of Action from Rio. In Proceedings of the United Nations Conference on Environment and Development (UNCED), Rio de Janeiro, Brazil, 3-14 June 1992; United Nations: New York, NY, USA, 1993.

35. United Nations Environment Programme. Convention on Biological Diversity. 1992. Available online: https://www.cbd.int/ doc/legal/cbd-en.pdf (accessed on 4 August 2021).

36. Garnett, S.T.; Burgess, N.D.; Fa, J.E.; Fernández-Llamazares, Á.; Molnár, Z.; Robinson, C.J.; Watson, J.E.; Zander, K.K.; Austin, B.; Brondizio, E.S.; et al. A spatial overview of the global importance of Indigenous lands for conservation. Nat. Sustain. 2018, 1, 369-374. [CrossRef]

37. O’Bryan, C.J.; Garnett, S.T.; Fa, J.E.; Leiper, I.; Rehbein, J.A.; Fernández-Llamazares, Á.; Jackson, M.V.; Jonas, H.D.; Brondizio, E.S.; Burgess, N.D.; et al. The importance of Indigenous Peoples' lands for the conservation of terrestrial mammals. Conserv. Biol. 2020, 35, 1002-1008. [CrossRef]

38. Fa, J.E.; Watson, J.E.; Leiper, I.; Potapov, P.; Evans, T.D.; Burgess, N.D.; Molnár, Z.; Fernández-Llamazares, Á.; Duncan, T.; Wang, S.; et al. Importance of Indigenous Peoples' lands for the conservation of Intact Forest Landscapes. Front. Ecol. Environ. 2020, 18, 135-140. [CrossRef]

39. Tsuji, L.; Ho, E. Traditional Environmental Knowledge and Western Science: In Search of Common Ground. Can. J. Nativ. Stud. 2002, 22, 327-360. Available online: http:/ / www3.brandonu.ca/cjns/22.2/cjnsv.22no.2_pg327-360.pdf (accessed on 23 July 2021).

40. Greer, S. Science: It's Not Just a White Man's Thing. Winds Chang. 1992, 7, 12-18.

41. Lalonde, A. African Indigenous Knowledge and Its Relevance to Sustainable Development. In Traditional Ecological Knowledge: Concepts and Cases; Inglis, J.T., Ed.; Canadian Museum of Nature: Ottawa, ON, Canada, 1993.

42. Marshall, A.; Bartlett, C. Two-Eyed Seeing: "taking down the boundaries" between Mi'kmaq Traditional Knowledge and the mainstream. In Proceedings of the Atlantic Aboriginal Economic Development Integrated Research Program, Darmouth, NS, Canada, 16-18 February 2010.

43. Constitution Act 1982. In A Consolidation of The Constitution Acts 1867 to 1982; Department of Justice Canada, Consolidated as of 1 January 2013; Public Works and Government Services Canada: Ottawa, ON, Canada, 2013.

44. Tsuji, S.R.J. Economic Recovery in Response to Worldwide Crises: Fiduciary Responsibility and the Legislative Consultative Process with Respect to Bill 150 (Green Energy and Green Economy Act, 2009) and Bill 197 (COVID-19 Economic Recovery Act, 2020) in Ontario, Canada. Int. Indig. Policy J. 2021, in press.

45. Rosenberg, D.M.; Bodaly, R.A.; Usher, P.J. Environmental and social impacts of large scale hydroelectric development: Who is listening? Glob. Environ. Chang. 1995, 5, 127-148. [CrossRef]

46. Rosenberg, D.M.; Berkes, F.; Bodaly, R.A.; Hecky, R.E.; Kelly, C.A.; Rudd, J.W. Large-scale impacts of hydroelectric development. Environ. Rev. 1997, 5, 27-54. [CrossRef]

47. Mattmann, M.; Logar, I.; Brouwer, R. Hydropower externalities: A meta-analysis. Energy Econ. 2016, 57, 66-77. [CrossRef]

48. Tremblay, A.; Lambert, M.; Gagnon, L. Do Hydroelectric Reservoirs Emit Greenhouse Gases? Environ. Manag. 2004, 33 (Suppl. S1), S509-S517. [CrossRef]

49. Grenier, M.; Labrecque, S.; Garneau, M.; Tremblay, A. Object-based classification of a SPOT-4 image for mapping wetlands in the context of greenhouse gases emissions: The case of the Eastmain region, Québec, Canada. Can. J. Remote Sens. 2008, 34 (Suppl. S2), S398-S413. [CrossRef]

50. Bastien, J.; Demarty, M.; Tremblay, A. $\mathrm{CO}_{2}$ and $\mathrm{CH}_{4}$ diffusive and degassing emissions from 2003 to 2009 at Eastmain 1 hydroelectric reservoir, Québec, Canada. Inland Waters 2011, 1, 113-123. [CrossRef]

51. Yan, X.; Thieu, V.; Garnier, J. Long-Term Evolution of Greenhouse Gas Emissions from Global Reservoirs. Front. Environ. Sci. 2021, 9, 705477. [CrossRef]

52. Bilotta, G.S.; Burnside, N.G.; Gray, J.C.; Orr, H.G. The Effects of Run-of-River Hydroelectric Power Schemes on Fish Community Composition in Temperate Streams and Rivers. PLoS ONE 2016, 11, e0154271. [CrossRef]

53. Bilodeau, F.; Therrien, J.; Schetagne, R. Intensity and duration of effects of impoundment on mercury levels in fishes of hydroelectric reservoirs in northern Québec (Canada). Inland Waters 2017, 7, 493-503. [CrossRef]

54. AMAP Assessment. Mercury in the Arctic; Arctic Monitoring and Assessment Programme: Oslo, Norway, 2011.

55. Renöfält, B.M.; Jansson, R.; Nilsson, C. Effects of hydropower generation and opportunities for environmental flow management in Swedish riverine ecosystems. Freshw. Biol. 2010, 55, 49-67. [CrossRef]

56. Anderson, D.; Moggridge, H.; Warren, P.; Shucksmith, J. The impacts of "run-of-river" hydropower on the physical and ecological condition of rivers. Water Environ. J. 2015, 29, 268-276. [CrossRef]

57. Colotelo, A.H.; Goldman, A.E.; Wagner, K.A.; Brown, R.S.; Deng, Z.D.; Richmond, M.C. A comparison of metrics to evaluate the effects of hydro-facility passage stressors on fish. Environ. Rev. 2017, 25, 1-11. [CrossRef]

58. Food and Agriculture Organization of the United Nations. Technical Fish Passes in Fish Passes—Design, Dimensions and Monitoring; FAO: Rome, Italy, 2002; pp. 69-101. Available online: http://www.fao.org/3/y4454e/y4454e00.htm (accessed on 4 August 2021).

59. Hatch. Northern Hydro Assessment Waterpower Potential in the Far North of Ontario (H345182-0000-00-124-0002, Rev. 3, November 26). 2013. Available online: http:/ / kabinakagami.northlandpower.ca/index.cfm?pagepath=Reports\&id=39980.htm (accessed on 4 August 2021).

60. Baxter, R. Environmental Effects of Dams and Impoundments. Annu. Rev. Ecol. Syst. 1977, 8, 255-283. [CrossRef] 
61. Mbaka, J.; Wanjiru Mwaniki, M. A global review of the downstream effects of small impoundments on stream habitat conditions and macroinvertebrates. Environ. Rev. 2015, 23, 257-262. [CrossRef]

62. Sholdice, M. The Ontario Experiment: Hydroelectricity, Public Ownership, and Transnational Progressivism, 1906-1939. Ph.D. Thesis, University of Guelph, Guelph, ON, Canada, January 2019.

63. Armstrong, J. A Political Economy of Native Marginalization: A Study of the Appropriation of Aboriginal Water Rights: The Case of the Mishkeegogamang First Nation. Ph.D. Thesis, Queen's University, Kingston, ON, Canada, 2000. Available online: https:/ / www.collectionscanada.gc.ca/obj/s4/f2/dsk3/ftp04/NQ56072.pdf (accessed on 4 August 2021).

64. Macfarlane, D.; Kitay, P. Hydraulic Imperialism: Hydroelectric Development and Treaty 9 in the Abitibi Region. Am. Rev. Can. Stud. 2016, 46, 380-397. [CrossRef]

65. Macfarlane, D.; Watson, A. Hydro Democracy: Water Power and Political Power in Ontario. Sci. Can. 2018, 40, 1-18. [CrossRef]

66. Tsuji, S.L.J.; Tsuji, J.S.R. Development on Indigenous Homelands and the need to get back to basics with scoping: Is there still "unceded" land in Northern Ontario, Canada, with respect to Treaty No. 9 and its Adhesions? Int. Indig. Policy J. 2021, 12, 1-49. [CrossRef]

67. Government of Canada. Library and Archives Canada: Treaty No. 9. 1905. Available online: https://www.collectionscanada. gc.ca / databases / treaties /001040-119.01-e.php?\&sisn_id_nbr=436\&interval=20\&\&PHPSESSID=5rudckpho0c1vis293hjncuu7 ppb5hqj0na5hno7en3sbpsohnd0 (accessed on 20 August 2021).

68. The James Bay Treaty: Treaty No. 9. Made in 1905 and 1906, and Adhesions made in 1929 and 1930. 1929. Cat. No. Ci 72-0964. QS-0577-OOO-EE-A-1. Reprinted from the edition of 1931 by Roger Duhamel, Queen's Printer and Controller of Stationary, Ottawa, Ontario, 1964. Available online: http://occc.ca/wp-content/uploads/2016/12/treaty-9-english-original-copy.pdf (accessed on 20 August 2021).

69. Tsuji, J.S.R.; Tsuji, S.L.J. Treaty No. 9 and the Question of "Unceded" Land South of the Albany River in Subarctic Ontario, Canada. ARCTIC 2021, in press.

70. Gardner, H.L.; Kirchhoff, D.; Tsuji, L.J. The Streamlining of the Kabinakagami River Hydroelectric Project Environmental Assessment: What is the "Duty to Consult" with Other Impacted Aboriginal Communities When the Co-Proponent of the Project is an Aboriginal Community? Int. Indig. Policy J. 2015, 6. [CrossRef]

71. Long, J.S. Treaty No. 9. Making the Agreement to Share the Land in Far Northern Ontario in 1905; McGill-Queen's University Press: Montreal, QC, Canada, 2010. [CrossRef]

72. Wildman, C.J.; Government of Ontario, Algoma, ON, Canada. To John Turner, Chairman of the Moose River/James Bay Coalition. Personal communication, 2 May 1993.

73. Ontario Power Generation. Peter Sutherland Sr. Hydro Station. 5 February 2020. Available online: https://www.opg.com/ strengthening-the-economy / our-projects/peter-sutherland-sr/ (accessed on 4 August 2021).

74. Ontario Waterpower Association. Footprints to Follow: Ontario Aboriginal Waterpower Case Studies. Available online: https:/ / www.owa.ca/wp-content/uploads/2017/02/Footprints-to-Follow-Ontario-Aboriginal-Case-Studies-1.pdf (accessed on 4 August 2021).

75. Kooses, D. Treaty Forum on “Rights to Water Resources". Forum Coordinator: Timmins, ON, Canada, 16-18 December 2008. Government of Ontario: Timmins, ON, Canada.

76. Mushkegowuk Environmental Research Centre. Fish Habitat Assessment of Potential Hydro Development Sites, Albany River; Mushkegowuk Environmental Research Centre: Timmins, ON, Canada, 2009.

77. Mushkegowuk Environmental Research Centre. Fish Research Mushkegowuk First Nations 2008-2009 Program; Mushkegowuk Environmental Research Centre: Timmins, ON, Canada, 2008.

78. WorldVu Geospatial Solutions. In University of Waterloo Albany River Dam Project; WorldVu Geospatial Solutions: Longmont, CO, USA; p. 2011.

79. Constance Lake First Nation; Northland Power Inc. Welcome You to the Kabinakagami River Project Public Information Centre, Tuesday; Northland Power Inc.: Toronto, ON, Canada, 6 December 2011.

80. Hatch. Northland Power Inc. Toronto Ontario: Project Description for Kabinakagami River Project; H338464-0000-07-124-0001, Rev. 1, 30 November 2011; Hatch Inc.: Mississauga, ON, Canada, 2011.

81. McEachren, J.; Whitelaw, G.; Mccarthy, D.; Tsuji, L. The Controversy of Transferring the Class Environmental Assessment Process to Northern Ontario, Canada: The Victor Mine Power Supply Project. Impact Assess. Proj. Apprais. 2011, 29, 109-120. [CrossRef]

82. Canadian Environmental Assessment Act (S.C. 1992, c. 37). Available online: https://laws-lois.justice.gc.ca/eng/acts/c-15.2/ (accessed on 4 August 2021).

83. Fortin, P. The hydro industry and the Aboriginal people of Canada: Paving the way for new relationships. Hydropower Dams 2001, $8,47-50$.

84. Canadian Environmental Assessment Act, 2012 (S.C. 2012, c. 19, s. 52). Available online: https://laws-lois.justice.gc.ca/eng/ acts /C-15.21/index.html (accessed on 4 August 2021).

85. Kirchhoff, D.; Tsuji, L. Reading between the lines of the "Responsible Resource Development" rhetoric: The use of omnibus bills to "streamline" Canadian environmental legislation. Impact Assess. Proj. Apprais. 2014, 32, 108-120. [CrossRef]

86. Kirchhoff, D.; Gardner, H.L.; Tsuji, L.J. The Canadian Environmental Assessment Act, 2012, and Associated Policy: Implications for Aboriginal Peoples. Int. Indig. Policy J. 2013, 4. [CrossRef] 
87. Impact Assessment Agency of Canada. Cumulative Effects Assessment Practitioners' Guide. 8 February 2020. Available online: https: / / iaac-aeic.gc.ca / default.asp?lang=En\&n=43952694-1\&toc=show\&offset=6 (accessed on 4 August 2021).

88. Environmental Assessment Act, R.S.O. 1990, c. E.18. Available online: https://www.ontario.ca/laws/statute/90e18 (accessed on 4 August 2021).

89. Kirchhoff, D.; Isogai, A.; Tsuji, L.J.S.; McCarthy, D.D.; Whitelaw, G. Kabinakagami River Project-Review of the Environmental Report; Correspondence of Chief Knapaysweet to the Ontario Minister of the Environment, Hon. Jim Bradley; Fort Albany First Nation: Fort Albany, ON, Canada; Ontario Ministry of Environment: Toronto, ON, Canada, 2013.

90. Ontario Power Generation and Moose Cree First Nation. Comprehensive Study Report: Lower Mattagami River Hydroelectric Complex Project. July 2009. Available online: https:/ / ceaa-acee.gc.ca/050/documents_staticpost/26302/38969E.pdf (accessed on 4 August 2021).

91. Hsieh, H.; Shannon, S. Three Approaches to Qualitative Content Analysis. Qual. Health Res. 2005, 15, 1277-1288. [CrossRef]

92. Charania, N.A.; Tsuji, L.J.S. A community-based participatory approach and engagement process creates culturally appropriate and community informed pandemic plans after the 2009 H1N1 influenza pandemic: Remote and isolated First Nations communities of sub-arctic Ontario, Canada. BMC Public Health 2012, 12, 268. [CrossRef]

93. Charania, N.A.; Tsuji, L.J.S. Recommended mitigation measures for an influenza pandemic in remote and isolated First Nations communities of Ontario, Canada: A community-based participatory research approach. Int. Indig. Policy J. 2014, 5, 1-22. [CrossRef]

94. Bryman, A.; Teevan, J.; Bell, E. Qualitative Data Analysis. In Social Research Methods Second Canadian Edition; Oxford University Press: Toronto, ON, Canada, 2009; pp. 251-276.

95. Mining Amendment Act, 2009, S.O. 2009, c. 21-Bill 173. Available online: https://www.ontario.ca/laws/statute/s09021 (accessed on 4 August 2021).

96. Far North Act (2010), S.O. 2010, c. 18. Available online: https://www.ontario.ca/laws/statute/10f18 (accessed on 4 August 2021).

97. Indian Act (R.S.C., 1985, c. I-5). 2011. Available online: https://laws-lois.justice.gc.ca/eng/acts/i-5/ (accessed on 4 August 2021).

98. Government of Ontario. Terms Commonly Used in Ontario Environmental Assessments. 2015; Updated July 2021. Available online: https:/ / www.ontario.ca/page/terms-commonly-used-ontario-environmental-assessments (accessed on 3 August 2021).

99. Solomon, A.; Fort Albany First Nation, Fort Albany, ON, Canada. To the Ontario Minister of the Environment, Hon. Jim Bradley. Personal communication, 11 May 2012.

100. Knapaysweet, R.; Fort Albany First Nation, Fort Albany, ON, Canada. To the Ontario Minister of the Environment, Hon. Jim Bradley. Personal communication, 4 March 2013.

101. McCarthy, D.B.; Whitelaw, G.S.; Tsuji, L. The Victor Diamond Mine environmental assessment and the Mushkegowuk Territory First Nations: Critical systems thinking and social justice. Can. J. Nativ. Stud. 2010, 30, 83-116.

102. Minkin, D.; Whitelaw, G.S.; McCarthy, D.D.; Tsuji, L.J. Cultural protection, empowerment and land use planning: Identification of values in support of Fort Albany First Nation, Ontario, Canada community based land use planning. Can. J. Nativ. Stud. 2014, 34, 129-150.

103. Beardy, S.G. Ontario, Standing Committee on General Government (Hansard). In Proceedings of the Legislative Assembly of Ontario, First Session, 39th Parliament, 6 August 2009. pp. 828-831. Available online: https://www.ola.org/en/legislativebusiness/bills/parliament-39/session-1/bill-173/debates (accessed on 1 January 2020).

104. McKay, S. Ontario, Standing Committee on General Government (Hansard). In Proceedings of the Legislative Assembly of Ontario, First Session, 39th Parliament, 11 August 2009. p. 912. Available online: https:/ /www.ola.org/sites/default/files/nodefiles/hansard/document/pdf/2009/2009-08/committee-transcript-1-EN-11-AUG-2009_G034.pdf (accessed on 4 August 2021).

105. Eckstein, G.; D’Andrea, A.; Marshall, V.; O’Donnell, E.; Talbot-Jones, J.; Curran, D.; O’Bryan, K. Conferring legal personality on the world's rivers: A brief intellectual assessment. Water Int. 2019, 44, 804-829. [CrossRef]

106. Corston, K. Ontario, Standing Committee on General Government (Hansard). In Proceedings of the Legislative Assembly of Ontario, First Session, 39th Parliament, 12 August 2009. pp. 955-956. Available online: https://www.ola.org/sites/ default/files/node-files/hansard/document/pdf/2009/2009-08/committee-transcript-1-EN-12-AUG-2009_G035.pdf (accessed on 23 July 2021).

107. Chiblow, S.; Meighan, P.J. Language is land, land is language: The importance of Indigenous languages. Hum. Geogr. 2021, 1-5. [CrossRef]

108. Windsor, J.E.; McVey, J.A. Annihilation of both place and sense of place: The experience of Cheslatta T'En Canadian First Nation within the context of large-scale environmental projects. Geogr. J. 2005, 171, 146-165. [CrossRef]

109. McGregor, D.; Whitaker, S.; Sritharan, M. Indigenous environmental justice and sustainability. Curr. Opin. Environ. Sustain. 2020, 43, 35-40. [CrossRef]

110. Rose, D.B. Nourishing Terrains: Australian Aboriginal Views of Landscape and Wilderness. Nourishing Terrains 1996. [CrossRef]

111. Burgess, C.P.; Johnston, F.H.; Berry, H.L.; McDonnell, J.; Yibarbuk, D.; Gunabarra, C.; Mileran, A.; Bailie, R.S. Healthy country, healthy people: The relationship between Indigenous health status and "caring for country". Med. J. Aust. 2009, $190,567$. [CrossRef]

112. Beardy, F. Ontario, Standing Committee on General Government (Hansard). In Proceedings of the Legislative Assembly of Ontario, First Session, 39th Parliament, 12 August 2009. p. 953. Available online: https://www.ola.org/sites/default/files/nodefiles/hansard/document/pdf/2009/2009-08/committee-transcript-1-EN-12-AUG-2009_G035.pdf (accessed on 23 July 2021). 
113. Hunter, G. Ontario, Standing Committee on General Government (Hansard). In Proceedings of the Legislative Assembly of Ontario, First Session, 39th Parliament, 12 August 2009. p. 956. Available online: https:/ /www.ola.org/sites/default/files/nodefiles/hansard/document/pdf/2009/2009-08/committee-transcript-1-EN-12-AUG-2009_G035.pdf (accessed on 23 July 2021).

114. Nishiiyuu Council of Elders. What You Do to Eeyou Istchee (Our Land), You Do to Eeyouch (Our People). Available online: http://archives.bape.gouv.qc.ca/sections/mandats/uranium-enjeux/documents/MEM26.pdf (accessed on 4 August 2021).

115. Tsuji, L.J.; Tsuji, S.R.; Zuk, A.M.; Davey, R.; Liberda, E.N. Harvest Programs in First Nations of Subarctic Canada: The Benefits Go beyond Addressing Food Security and Environmental Sustainability Issues. Int. J. Environ. Res. Public Health 2020, $17,8113$. [CrossRef] [PubMed]

116. AMAP. AMAP Assessment 2009: Human Health in the Arctic. Arctic Monitoring and Assessment Programme (AMAP), Oslo, Norway. 2009. xiv+254p. Available online: https://www.amap.no/documents/download/1163/inline (accessed on 4 August 2021).

117. Scelza, B.A.; Bird, D.W.; Bliege Bird, R. Bush tucker, shop tucker: Production, consumption, and diet at an aboriginal outstation. Ecol. Food Nutr. 2014, 53, 98-117. [CrossRef]

118. O'Dea, K. Marked improvement in carbohydrate and lipid metabolism in diabetic Australian Aborigines after temporary reversion to traditional lifestyle. Diabetes 1984, 33, 596. [CrossRef] [PubMed]

119. Naughton, J.M.; O’Dea, K.; Sinclair, A.J. Animal foods in traditional Australian aboriginal diets: Polyunsaturated and low in fat. Lipids 1986, 21, 684. [CrossRef]

120. O'Dea, K. Traditional diet and food preferences of Australian Aboriginal hunter-gatherers. Royal Society 1991, 334. [CrossRef]

121. Solomon, J. Ontario, Standing Committee on General Government (Hansard). In Proceedings of the Legislative Assembly of Ontario, First Session, 39th Parliament, 12 August 2009. p. 954. Available online: https:/ /www.ola.org/sites/default/files/nodefiles/hansard/document/pdf/2009/2009-08/committee-transcript-1-EN-12-AUG-2009_G035.pdf (accessed on 23 July 2021).

122. Solomon, A. Ontario, Standing Committee on General Government (Hansard). In Proceedings of the Legislative Assembly of Ontario, First Session, 39th Parliament, 12 August 2009. p. 953. Available online: https://www.ola.org/sites/default/files/nodefiles/hansard/document/pdf/2009/2009-08/committee-transcript-1-EN-12-AUG-2009_G035.pdf (accessed on 23 July 2021).

123. Hall, T. Ontario, Standing Committee on General Government (Hansard). In Proceedings of the Legislative Assembly of Ontario, First Session, 39th Parliament, 13 August 2009. p. 981. Available online: https:/ /www.ola.org/sites/default/files/node-files/ hansard/document/pdf/2009/2009-08/committee-transcript-1-EN-13-AUG-2009_G036.pdf (accessed on 1 January 2020).

124. Neufeld, H.T.; Richmond, C.; Southwest Ontario Aboriginal Health Access Centre. Exploring First Nation Elder Women's Relationships with Food from Social, Ecological, and Historical Perspectives. Curr. Dev. Nutr. 2020, 4, nzaa011. [CrossRef]

125. Moriarity, R.J.; Zuk, A.M.; Liberda, E.N.; Tsuji, L.J. Health measures of Eeyouch (Cree) who are eligible to participate in the on-the-land Income Security Program in Eeyou Istchee (northern Quebec, Canada). BMC Public Health 2021, 21, 628. [CrossRef]

126. Tsuji, L.J.S. The use of modified school years: An important local control of education issue. Can. J. Nativ. Educ. 2000, 24, 158-168.

127. Stone, R.A.T.; Whitbeck, L.B.; Chen, X.; Johnson, K.; Olson, D.M. Traditional practices, traditional spirituality, and alcohol cessation among American Indians. J. Stud. Alcohol 2006, 67, 236-244. [CrossRef]

128. Johnson-Jennings, M.; Billiot, S.; Walters, K. Returning to Our Roots: Tribal Health and Wellness through Land-Based Healing. Genealogy 2020, 4, 91. [CrossRef]

129. Warbrick, I.; Wilson, D.; Boulton, A. Provider, father, and bro-Sedentary Maori men and their thoughts on physical activity. Int. J. Equity Health 2016, 15, 22. [CrossRef] [PubMed]

130. Janelle, A.; Laliberté, A.; Ottawa, U. Promoting traditions: An evaluation of a wilderness activity among first nations of Canada. Australas. Psychiatry 2009, 17 (Suppl. S1), S108-S111. [CrossRef] [PubMed]

131. Akbar, L.; Zuk, A.M.; Martin, I.D.; Liberda, E.N.; Tsuji, L.J. Potential obesogenic effect of a complex contaminant mixture on Cree First Nations adults of Northern Quebec, Canada. Environ. Res. 2021, 192, 110478. [CrossRef] [PubMed]

132. Ahmed, F.; Zuk, A.M.; Tsuji, L.J. The Impact of Land-Based Physical Activity Interventions on Self-Reported Health and Well-Being of Indigenous Adults: A Systematic Review. Int. J. Environ. Res. Public Health 2021, 18, 7099. [CrossRef]

133. Moriarity, R.J.; Zuk, A.M.; Liberda, E.N.; Tsuji, L.J. The self-reported behaviour of Iiyiyiu Aschii Cree and the worry about pollution from industrial and hydroelectric development in northern Quebec, Canada. Environ. Res. 2021, 195, 110788. [CrossRef]

134. Babin, D. Ontario, Standing Committee on General Government (Hansard). In Proceedings of the Legislative Assembly of Ontario, First Session, 39th Parliament, 12 August 2009. p. 955. Available online: https:/ /www.ola.org/sites/default/files/nodefiles/hansard/document/pdf/2009/2009-08/committee-transcript-1-EN-12-AUG-2009_G035.pdf (accessed on 23 July 2021).

135. Robertson, S.; Ljubicic, G. Nunamii'Iuni quvianaqtuq (It is a happy moment to be on the land): Feelings, freedom and the spatial political ontology of well-being in Gjoa Haven and Tikiranajuk, Nunavut. EPD Soc. Space 2019, 37, 542-560. [CrossRef]

136. The Whanganui River Report. Waitangi Tribunal Report 1999; GP Publications: Wellington, New Zealand, 1999.

137. New Zealand Legislation. Te Awa Tupua (Whanganui River Claims Settlement) Act 2017. 2017. Available online: https: / / www.legislation.govt.nz/act/public/2017/0007/latest/whole.html (accessed on 4 August 2021).

138. McEachren, J. Unpublished Interview. 21 February 2007.

139. Koostachin, G. Ontario, Standing Committee on General Government (Hansard). In Proceedings of the Legislative Assembly of Ontario, First Session, 39th Parliament, 12 August 2009. p. 958. Available online: https://www.ola.org/sites/default/files/nodefiles/hansard/document/pdf/2009/2009-08/committee-transcript-1-EN-12-AUG-2009_G035.pdf (accessed on 23 July 2021). 
140. Northland Power Inc. Third-Quarter Report: Quarterly Report for the Period Ended September 30, 2014. (3rd Quarter 2014 Report) Northland Power Inc. Available online: https: / / financedocbox.com/Investing/67859580-Northland-power-inc-third-quarterreport-quarterly-report-for-the-period-ended-september-30-2014.html (accessed on 4 August 2021).

141. Heron, L. Ontario Rivers Alliance. 2016-2017 Annual Report: Annual General Meeting. 21 October 2017. Available online: https:/ / www.ontarioriversalliance.ca/wp-content/uploads/2014/05/2016-2017-ORAAnnualReport1.pdf (accessed on 4 August 2021).

142. Northland Power. Northland Power. 2021. Available online: https://www.northlandpower.com/en/index.aspx (accessed on 4 August 2021).

143. Hatch. Draft Environmental Report for the Kabinakagami River Project; H338464-0000-07-124-0007; Hatch Inc.: Mississauga, ON, Canada, 2012.

144. Willyard, C.J.; Tikalsky, S.M.; Mullins, P.A. Ecological Effects of Fragmentation Related to Transmission Line Rights-of-Way: A Review of the State of the Science; Resource Strategies, Inc.: Cleveland, OH, USA, 2004.

145. Manitoba Hydro. Fur, Feathers, Fins \& Transmission Lines: How Transmission Lines and Rights-Of-Way Affect Wildlife. 2010. Available online: https://www.hydro.mb.ca/environment/pdf/fur_feathers_fins_and_transmission_lines.pdf (accessed on 4 August 2021).

146. Reed Harris Environmental Ltd. Potential for Increased Fish Mercury Concentrations Associated with the Proposed Kabinakagami River Hydroelectric Project; Reed Harris Environmental Ltd.: Oakville, ON, Canada, 2012.

147. Tsuji, L.; Nieboer, E. Question of Sustainability in Cree Harvesting Practices: The Seasons, Technological and Cultural Changes in the Western James Bay Region of Northern Ontario, Canada. Can. J. Nativ. Stud. 1999, 19, 169-192.

148. Moriarity, R.J.; Liberda, E.N.; Tsuji, L.J. Subsistence fishing in the Eeyou Istchee (James Bay, Quebec, Canada): A regional investigation of fish consumption as a route of exposure to Methylmercury. Chemosphere 2020, 258, 127413. [CrossRef]

149. Gelinas, J.; Horswill, D.; Northey, R.; Pelletier, R. Building Common Ground: A New Vision for Impact Assessment in Canada. In Expert Panel Review of Environmental Assessment Processes; Canadian Environmental Assessment Agency: Ottawa, ON, Canada, 2017; Available online: https:/ /www.canada.ca/en/services/environment/conservation/assessments/environmental-reviews/ environmental-assessment-processes/building-common-ground.html (accessed on 4 August 2021).

150. Impact Assessment Act (S.C. 2019, c. 28, s. 1). Available online: https://laws.justice.gc.ca/eng/acts/I-2.75/index.html (accessed on 4 August 2021).

151. Almeida, R.M.; Shi, Q.; Gomes-Selman, J.M.; Wu, X.; Xue, Y.; Angarita, H.; Barros, N.; Forsberg, B.R.; García-Villacorta, R.; Hamilton, S.K.; et al. Reducing greenhouse gas emissions of Amazon hydropower with strategic dam planning. Nat. Commun. 2019, 10, 4281. [CrossRef]

152. COVID-19 Economic Recovery Act, 2020. S.O. 2020, c.18. Available online: https://www.ontario.ca/laws/statute/s20018 (accessed on 4 August 2021).

153. Government of Ontario. Ontario Low-Carbon Hydrogen Strategy Discussion Paper. 2020. Available online: https://ero.ontario. ca/notice/019-2709 (accessed on 4 August 2021).

154. Government of Canada. Powering Our Future with Clean Electricity. 2020. Available online: https://www.canada. $\mathrm{ca} / \mathrm{en} /$ services/environment/weather/climatechange/climate-action/powering-future-clean-energy.html (accessed on 23 December 2020).

155. Statistics Canada. The Social and Economic Impacts of COVID-19: A Six-Month Update. 2020. Available online: https: //www150.statcan.gc.ca/n1/pub/11-631-x/11-631-x2020004-eng.htm (accessed on 20 August 2021).

156. Rosenbloom, D.; Markard, J. A COVID-19 recovery for climate. Science 2020, 368, 447. [CrossRef]

157. Markrard, J.; Rosenbloom, D. A tale of two crises: COVID-19 and climate. Sustain. Sci. Pract. Policy 2020, 16, 53-60. [CrossRef]

158. International Energy Agency. Renewable Power. 2021. Available online: http://www.iea.org/reports/renewable-power (accessed on 4 August 2021). 